\title{
Compositional zoning of garnet porphyroblasts from the polymetamorphic Wölz Complex, Eastern Alps
}

\author{
Journal Article \\ Author(s): \\ Bestel, Martina; Gawronski, Timo; Abart, Rainer; Rhede, Dieter \\ Publication date: \\ 2009-12-01 \\ Permanent link: \\ https://doi.org/10.3929/ethz-b-000083801
}

Rights / license:

In Copyright - Non-Commercial Use Permitted

Originally published in:

Mineralogy and Petrology 97(3-4), https://doi.org/10.1007/s00710-009-0084-z 


\title{
Compositional zoning of garnet porphyroblasts from the polymetamorphic Wölz Complex, Eastern Alps
}

\author{
Martina Bestel • Timo Gawronski • Rainer Abart • \\ Dieter Rhede
}

Received: 18 December 2008 / Accepted: 24 September 2009 /Published online: 21 October 2009

(C) Springer-Verlag 2009

\begin{abstract}
We employ garnet isopleth thermobarometry to derive the $\mathrm{P}-\mathrm{T}$ conditions of Permian and Cretaceous metamorphism in the Wölz crystalline Complex of the Eastern Alps. The successive growth increments of two distinct growth zones of the garnet porphyroblasts from the Wölz Complex indicate garnet growth in the temperature interval of $540^{\circ} \mathrm{C}$ to $560^{\circ} \mathrm{C}$ at pressures of 400 to $500 \mathrm{MPa}$ during the Permian and temperatures ranging from $550^{\circ} \mathrm{C}$ to $570^{\circ} \mathrm{C}$ at pressures in the range of 700 to $800 \mathrm{MPa}$ during the Cretaceous Eo-Alpine event. Based on diffusion modelling of secondary compositional zoning within the outermost portion of the first garnet growth zone constraints on the timing of the Permian and the Eo-Alpine metamorphic events are derived. We infer that the rocks remained in a temperature interval between $570^{\circ} \mathrm{C}$ and $610^{\circ} \mathrm{C}$ over about 10 to $20 \mathrm{Ma}$ during the Permian, whereas the high temperature stage of the Eo-Alpine event only lasted for about 0.2 Ma. Although peak metamorphic temperatures never exceeded $620^{\circ} \mathrm{C}$, the prolonged thermal annealing
\end{abstract}

Editorial handling: F. Gaidies and T. John

M. Bestel $(\bowtie)$

Labor für Neutronenstreuung,

ETH Zürich \& Paul Scherrer Insitut,

5232 Villigen, PSI, Switzerland

e-mail: martina.bestel@psi.ch

T. Gawronski

Institute of Geological Sciences, Free University Berlin,

Malteserstrasse 74-100,

12249 Berlin, Germany

R. Abart

Department für Lithosphärenforschung, Universität Wien,

Althanstrasse 14,

1090 Wien, Austria

D. Rhede

Helmholtzzentrum Potsdam, Deutsches GeoForschungsZentrum,

Telegrafenberg,

14473 Potsdam, Germany during the Permian produced several $100 \mu \mathrm{m}$ wide alteration halos in the garnet porphyroblasts and partially erased their thermobarometric memory. Short diffusion profiles which evolved around late stage cracks within the first garnet growth zone constrain the crack formation to have occurred during cooling below about $450^{\circ} \mathrm{C}$ after the Eo-Alpine event.

\section{Introduction}

The Wölz crystalline basement pertains to the Austroalpine basement east of the Tauern window. The Austroalpine basement represents the former frontal part of the Apulian micro-continent, which was thrust over Penninic and Helvetic units during the Alpine orogeny. The Austroalpine basement comprises meta-igneous and meta-sedimentary units. At least three regional metamorphic events are documented from the Austroalpine basement (Schuster et al. 2004; Schmid et al. 2004; Gaidies et al. 2008c). A first metamorphic event was of Barrovian type and produced greenschist and amphibolite facies conditions in wide portions of the basement. This event is ascribed to the Variscan orogeny. A second metamorphic event was of low-pressure type and is dated at $260 \mathrm{Ma}$ (Schuster and Thöni 1996). A third metamorphic event is of Barrovian type and is dated at $\sim 90 \mathrm{Ma}$ (Thöni 2002, 2006). The third metamorphic event is ascribed to the continent-continent collision during the Eo-Alpine orogeny. In the Sau- and Koralpe Complexes, which represent the southern portion of the Austroalpine basement, eclogite facies conditions were reached during the Eo-Alpine orogeny. In the Wölz crystalline basement, which is located further north, amphibolite facies conditions were attained with pressures up to 1.2 GPa (Faryad and Hoinkes 2003; Gaidies et al. 2006, 2008b, c).

The Wölz Crystalline basement comprises two prominent tectonic units, the Wölz Complex and the Rappold Complex. Both these complexes are primarily comprised of garnet bearing micaschists. The garnets typically have two 
distinct growth zones. The first growth zone forms the core regions of the garnet porphyroblasts and the second growth zone the rims. In both tectonic units the second growth zone is ascribed to the Eo-Alpine metamorphic event (Schuster and Frank 1999; Schuster and Thöni 1996; Thöni 2002). The transition from Grt I to Grt II is well defined by a compositional discontinuity. The first garnet growth zone is the prime remnant of the pre-Eo-Alpine metamorphic evolution. This motivated the use of garnet isopleth thermobarometry for the reconstruction of the pre-Eo-Alpine metamorphic history (Gaidies et al. 2006, 2008b, c). In garnet isopleth thermobarometry garnet isopleths are constructed based on thermodynamic data implying that thermodynamic equilibrium was attained among all phases present in the rock of specified bulk composition (e.g. Spear and Selverstone 1983; Vance and Holland 1993; Gaidies et al. 2006). In case that each successive growth increment of garnet grew in equilibrium with the rock matrix and the original growth zoning is preserved, the isopleths, which correspond to observed garnet compositions, intersect at a point or define a small area of intersection. This intersection indicates the pressure and temperature conditions which prevailed during garnet growth. An important potential of garnet isopleth thermobarometry is its applicability to successive growth increments of a garnet porphyroblast, i.e. in principle the entire $\mathrm{P}-\mathrm{T}$ trajectory, which was followed during garnet growth, may be reconstructed from the observed growth zoning.

For this study we selected two samples from the Wölz Complex and one from the Rappold Complex for reconstruction of the metamorphic conditions during the Permian and Eo-Alpine metamorphic events by means of garnet isopleth thermobarometry. In addition we investigated re-equilibration phenomena, which occur at the outer rims of the garnet cores or at the interfaces of the garnet cores with large mineral inclusions or quartz filled fractures. These re-equilibration phenomena were analysed based on a model for diffusion controlled chemical exchange between the garnet porphyroblasts and the rock matrix and for diffusion exchange between the first and second garnet growth zones. From this analysis we infer the distances over which the original growth zoning of a garnet porphyroblast may be altered due to diffusion exchange and we rederived constraints on the timing of the Permian and Eo-Alpine metamorphic events. In addition, short diffusion profiles, which developed around late stage fractures within the first garnet growth zone were analyzed and constraints on the temperature interval over which fracturing occurred are derived.

\section{Geological background}

The Eastern Alps form a 500-km-long east-west trending fold and thrust belt, which experienced a complex tectono- metamorphic evolution (Schmid et al. 2004). In the Cretaceous the Apulian micro-continent collided with the European plate. This caused substantial shortening of the crust by intracontinental subduction, WNW-directed thrusting at all structural levels and the formation of large décollement nappes in the uppermost crustal levels. A second thrusting event was associated with the closure of the Penninic ocean in the Tertiary.

The major portion of the Eastern Alps pertains to the Austroalpine nappe system, which represents the former frontal part of the Apulian micro-continent. The Northern Calcareous Alps represent the highest structural level of the Austroalpine realm. The Austroalpine basement units represent the structurally lower level. The Kor-Saualpe Complexes and the Wölz crystalline basement represent prominent portions of the Austroalpine basement east of the Tauern window (see Fig. 1). These units pertained to the lower plate during the Cretaceous intracontinental subduction. They experienced greenschist, amphibolite and eclogite facies metamorphic overprint during the EoAlpine event, where metamorphic grade increases from north (Wölz crystalline basement) towards the south (SauKoralpe Complexes). The suture of the Cretaceous subduction is discernable in the southern part of the Austroalpine basement, and it is only recognized from the lack of EoAlpine metamorphism to the south of a mappable line, which delimits the southern border of alpine metamorphism, the so called SAM (Hoinkes et al. 1999). In terms of lithology, tectonic position and metamorphic grade there is a gradual transition from the Wölz crystalline basement in the north to the Kor-Saualpe Complexes in the south. The Wölz crystalline basement rests on the tectonically deeper basement units of the Schladming and Bösenstein Seckau crystalline units, which are part of the Silvretta-Seckau nappe system (Fig. 1).

\section{Metamorphic history of the Wölz crystalline basement}

The Wölz crystalline basement is primarily comprised of metapelitic lithologies with minor intercalations of amphibolites and marbles. The protoliths are probably of lower Paleozoic age (Abart and Martinelli 1989). Within the Wölz crystalline basement two major complexes, the Wölz Complex and the Rappold Complex are discerned based on lithological criteria and on their metamorphic history.

The Wölz Complex is primarily comprised of garnet bearing micaschists. In the Wölz Complex garnet usually shows two distinct growth zones. Typically the two growth zones form the core and rim regions of garnet porphyroblasts (see Fig. 2). The two growth zones grew over different fabrics indicating a time hiatus at the boundary between the two growth zones. The garnet cores will 


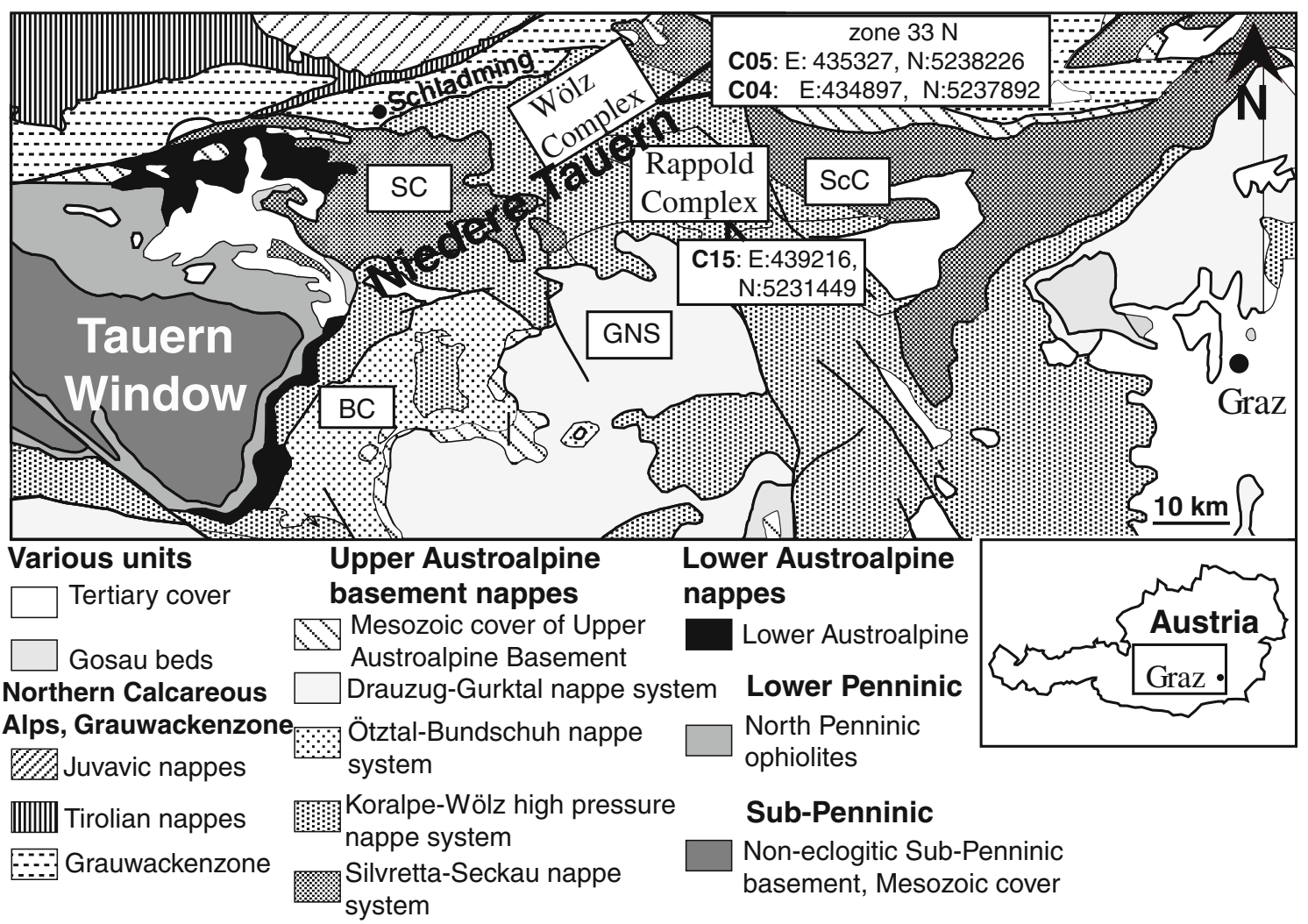

Fig. 1 Simplified tectonic map of the Austroalpine basement units east of the Tauern window and the location of the samples C04, C05 and C15. Modified from Gaidies et al. (2006). SC: Schladming Complex; ScC: Seckau Complex; GNS: Gurktal nappe system; BC: Bundschuh Complex

henceforth be referred to as Grt I and the rim regions will be referred to as Grt II. Based on garnet isopleth thermobarometry Grt I in the garnet micaschists of the Wölz Complex grew at relatively low pressures of about 400 to $450 \mathrm{MPa}$ and at temperatures of about 540 to $560^{\circ} \mathrm{C}$ (Gaidies et al. 2006). Using the Sm-Nd garnet-whole-rock method Grt I has been dated at $269 \pm 4 \mathrm{Ma}$ (Schuster and Thöni 1996), and it is interpreted as the product of low-pressure high-

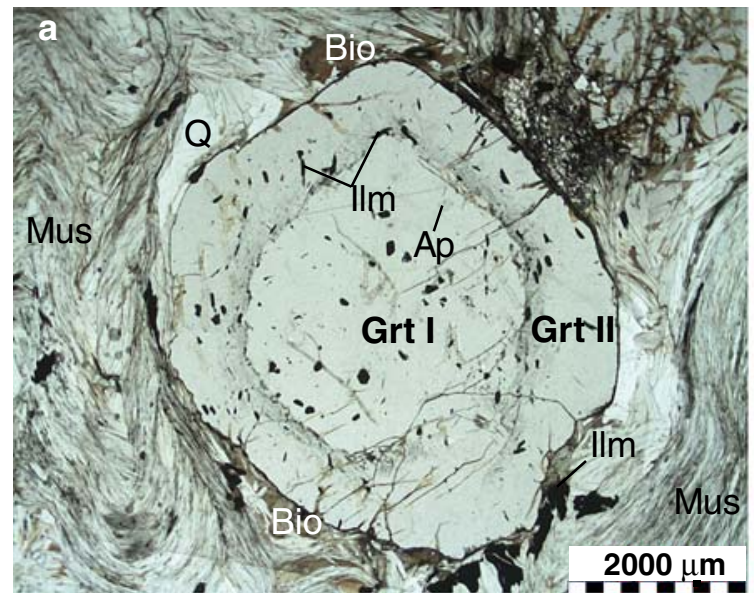

Fig. 2 Photo micrographs of garnet porphyroblasts from selected samples from the Wölz Complex; a garnet porphyroblast with two distinct growth zones, Grt I is of Permian age, Grt II is of Cretaceous temperature metamorphism during the late Permian-early Triassic. The low pressures indicate high heat flux in an extensional regime, possibly associated with initial thinning within the Apulian micro continent (Schuster et al. 2001). Grt II started to grow at significantly higher pressures of about 650 to $700 \mathrm{MPa}$ and temperatures of about 540 to $550^{\circ} \mathrm{C}$ (Gaidies et al. 2006, 2008b). It is ascribed to the EoAlpine metamorphic event (Schuster and Frank 1999;

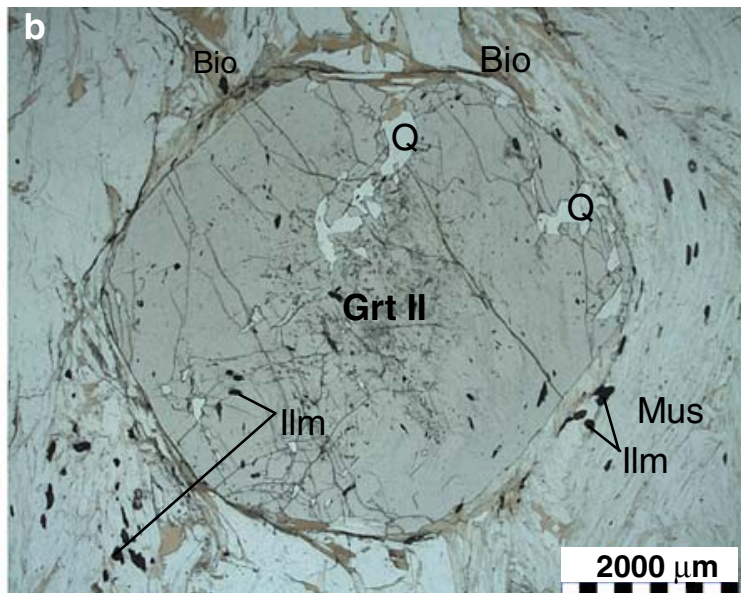

age; b garnet porphyroblast with only one growth zone, Grt II; note that both garnet growth zones have abundant inclusions of quartz and ilmenite 
Schuster and Thöni 1996; Thöni 2002), which is associated with the intracontinental subduction during the Cretaceous. The peak of the Eo-alpine metamorphic event was dated at $92 \mathrm{Ma}$ (Thöni 2002, 2006).

The Rappold Complex is lithologically more diverse than the Wölz Complex with micaschists, paragneisses, amphibolites and marbles. The metapelitic lithologies are garnet-bearing, with minor occurrences of staurolite and kyanite. Like in the Wölz Complex garnet typically shows two growth zones albeit with a different microstructure than garnet from the Wölz Complex.

In the Rappold Complex Grt I has a maximum size of seven $\mathrm{mm}$ in diameter and Grt II is usually less than two $\mathrm{mm}$. Grt II of the Rappold Complex is usually thinner than Grt II of the Wölz Complex. Grt I grew over a fine-grained fabric, which is best seen from black pigment (supposedly finely dispersed graphite). This pigment is also enclosed by large staurolite grains which show smooth boundaries with Grt I indicating stable coexistence of the two phases. Based on garnet isopleth thermobarometry Grt I from the Rappold Complex started to grow at about 530-560 MPa and 525$540^{\circ} \mathrm{C}$ (Gaidies et al. 2006, 2008c). Grt I from the Rappold Complex has not been dated yet, but it may represent a remnant of pre-Eo-Alpine metamorphism. Considering the relatively high pressures obtained for its incipient growth it does not fit into the tectonometamorphic context of the Permian low-pressure metamorphism. It rather pertains to another pre-Eo-Alpine Barrovian-type metamorphic event possibly associated with the Variscan orogeny (Gaidies et al. 2008c). The thin rims and seams of idiomorphic Grt II grew at a pressure of 650 to $700 \mathrm{MPa}$ and 540 to $550^{\circ} \mathrm{C}$. They pertain to the Cretaceous Eo-Alpine event. It is likely that the Rappold Complex also experienced Permian low-pressure high-temperature metamorphism but this is less evident than in the Wölz Complex (Gaidies et al. 2006, 2008c). Due to the fact that garnet had already been formed at mediumpressure conditions during the Variscan orogeny garnet was not thermodynamically stable at the low-pressure conditions of the Permian event. Grt I from the Rappold Complex seems to have been partially resorbed during the Permian overprint. Only at higher-pressure conditions of the EoAlpine event garnet became stable again so that Grt II could grow. Typically staurolite became unstable too during the Eo-Alpine overprint and garnet formed at staurolite/quartz contacts (Abart and Martinelli 1989) and at staurolite/ muscovite contacts (Prenzel and Abart 2009).

\section{Analytical methods}

Microprobe analyses were done with a JEOL JXA-8200 Superprobe equipped with WDS detectors at Free University Berlin. An acceleration voltage of $15 \mathrm{kV}$ and a beam current of
$20 \mathrm{nA}$ were applied. Natural and synthetic mineral standards were used for calibration, and matrix correction was done using a ZAF routine. Element distribution maps were prepared in stage scan mode using 100 milliseconds dwell time per pixel and ca. $20 \mu \mathrm{m}$ step size. High spatial resolution element maps were prepared with the JEOL thermal field-emission electron-probe JXA-8500F (Hyperprobe) at the GFZ German Research Centre for Geosciences in Potsdam. The element distribution maps were produced in WDS mode with an acceleration voltage of $8 \mathrm{kV}$, a beam current of $30 \mathrm{nA}$, stage scanning mode, and dwell times between $100 \mathrm{~ms}$ and $400 \mathrm{~ms}$ per pixel. A liquid nitrogen trap was used to minimize surface contamination during mapping. High-resolution point analyses were made at $8 \mathrm{kV}$ acceleration voltages yielding a spatial resolution of better than $500 \mathrm{~nm}$ for $\mathrm{Si}, \mathrm{Al}, \mathrm{Mg}$ and $\mathrm{Ca}$, and better than $300 \mathrm{~nm}$ for $\mathrm{Fe}$ and $\mathrm{Mn}$.

To obtain central sections through the garnet porphyroblasts serial thin sections were produced with a spacing of ca. $1 \mathrm{~mm}$. The central sections of garnet porphyroblasts were identified as the sections with the largest radius of the respective porphyroblast assuming that the crystals are spherical and that the geometric and chemical cores coincide.

Bulk rock compositions were determined using X-ray fluorescence spectroscopy on glass pellets prepared from rock powders mixed with $\mathrm{LiB}_{4}$ flux at $0.6 \mathrm{~g}: 3.6 \mathrm{~g}$ sample : flux proportions per weight and $\pm 1 \mathrm{~g} \mathrm{NH}_{4} \mathrm{NO}_{3}$ to reduce melt viscosity. A SRS 3000 instrument at Museum of Nature Berlin was used.

\section{Results}

Petrography

Two samples from the Wölz Complex, samples C04 and C05, and one sample from the Rappold Complex, sample C15, were selected for petrographic investigation and petrologic analysis. Brief sample descriptions and the coordinates of the sampling localities are given in Table 1 .

All investigated samples are garnet bearing micaschists. The foliation is defined by the alignment of muscovite, biotite, chlorite and subordinate paragonite, which together with quartz, K-feldspar, albite and tourmaline form the rock matrix. The garnet porphyroblasts are up to 5 millimetres in diameter. Most of the garnet porphyroblasts show two distinct growth zones (see Fig. 2): Grt I represents the inner growth zone forming garnet cores and Grt II represents the outer growth zone forming garnet rims. Some of the smaller porphyroblasts only have a single growth zone representing Grt II (see Fig. 2b).

The main foliation usually bends around the garnet porphyroblasts indicating that deformation outlasted garnet 
Table 1 Brief sample description and sample coordinates; sample coordinates refer to UTM projection and WGS 84 ellipsoid

\begin{tabular}{|c|c|c|c|c|}
\hline Sample & $\begin{array}{l}\text { Rock } \\
\text { type }\end{array}$ & $\begin{array}{l}\text { Mineral } \\
\text { assemblage }\end{array}$ & $\begin{array}{l}\text { Accessory } \\
\text { minerals }\end{array}$ & $\begin{array}{l}\text { Coordinates } \\
\text { (zone } 33 \mathrm{~N} \text { ) }\end{array}$ \\
\hline $\mathrm{C} 04$ & $\begin{array}{l}\text { Garnet } \\
\text { mica schist }\end{array}$ & $\begin{array}{l}\text { bio, mus, pa, } \\
\text { chl, ab, kfs, } \\
\text { grt, qtz, tur }\end{array}$ & $\begin{array}{l}\text { tur, ep, ilm, rt, } \\
\text { ap, ctd, ky, } \\
\text { zk, gr }\end{array}$ & $\begin{array}{l}E: 434897 \\
\text { N:5237892 }\end{array}$ \\
\hline $\mathrm{C} 05$ & $\begin{array}{l}\text { Garnet } \\
\text { mica schist }\end{array}$ & $\begin{array}{l}\text { bio, mus, pa, } \\
\text { chl, ab, kfs, } \\
\text { grt, tur, qtz }\end{array}$ & $\begin{array}{l}\text { tur, ep, ilm, } \\
\text { rt, ap, ctd, ky, } \\
\text { zk, gr }\end{array}$ & $\begin{array}{l}E: 435327 \\
N: 5238226\end{array}$ \\
\hline C15 & $\begin{array}{l}\text { Garnet } \\
\text { mica schist }\end{array}$ & $\begin{array}{l}\text { bio, mus, chl, } \\
\text { ab, kfs, ser, } \\
\text { grt, tur, qtz }\end{array}$ & $\begin{array}{l}\text { tur, ep, ky, stau, } \\
\text { cal, ilm, rt, gr }\end{array}$ & $\begin{array}{l}E: 439216 \\
N: 5231449\end{array}$ \\
\hline
\end{tabular}

formation. Some foliation-parallel trails of finely dispersed opaque phases can be traced from the matrix into Grt II. The inclusion trails usually change orientation at the garnetmatrix interface indicating syntectonic growth of Grt II. In C15 a large garnet porphyroblast was fractured during ductile deformation leaving behind two fragments, which are separated by an intervening quartz-filled vein (see Fig. 7). It is important to note that along the fractures of garnet in $\mathrm{C} 15$ the interior of Grt I is directly exposed to the quartz matrix that fills the fracture without any overgrowth of Grt II. This may indicate that fracturing postdates Grt II growth, i.e. that fracturing occurred during a late stage of the Eo-Alpine evolution. Alternatively Grt I of C15 may have been fractured earlier but the local chemical environment within the quartz filled fracture was unfavourable for Grt II growth so that Grt II did not form although the fracture already existed during the Eo-Alpine event. This issue will be discussed further in the light of secondary chemical zoning of Grt I at its interface to the quartz filled fracture.

The two garnet growth zones show different inclusion assemblages. Whereas Grt I typically has only relatively few inclusion of quartz, paragonite, muscovite, tourmaline, apatite, chloritoid, ilmenite and rutile these inclusions are more abundant in Grt II. They accumulate particularly in the innermost portion of Grt II.

Rutile and ilmenite are present in the matrix and as inclusions in Grt I and II. Frequently rutile grains in the matrix have rims of ilmenite indicating rutile to ilmenite transformation. Allanite and monazite are easily identified from their pleochroic halos in biotite. Monazite grains in the matrix are often rimmed by allanite (Fig. 3) indicating monazite to allanite reaction. Monazite is also present as inclusions in Grt I and Grt II. Xenomorphic allanite is present together with biotite along cracks in Grt I and II.

Bulk rock composition

The bulk rock compositions of $\mathrm{C} 05, \mathrm{C} 15$ and $\mathrm{C} 04$ are listed in Table 2. The bulk rock composition of $\mathrm{C} 05$ is very similar to the average pelite composition of Symmes and Ferry (1991). Only with respect to the $\mathrm{Al}_{2} \mathrm{O}_{3}$ content it is about $5 \mathrm{wt} \%$ higher than the average pelite and with respect to $\mathrm{CaO}$ it is significantly $(1.5 \mathrm{wt} \%)$ lower.

In $\mathrm{C} 04$ and $\mathrm{C} 15$ the concentration of $\mathrm{SiO}_{2}$ is about $7 \mathrm{wt} \%$ lower and the concentration of $\mathrm{Al}_{2} \mathrm{O}_{3}$ is slightly higher than in sample $\mathrm{C} 05$. $\mathrm{C} 04$ shows similarly low $\mathrm{CaO}$ contents as C05. In addition $\mathrm{Fe}_{2} \mathrm{O}_{3}$ is about $3.2 \mathrm{wt} \%$ higher than in the average composition of Symmes and Ferry (1991). In C15 the $\mathrm{CaO}$ content is about $0.33 \mathrm{wt} \%$ higher than in $\mathrm{C} 04$ and $\mathrm{C} 05$.

\section{Garnet growth zoning}

Garnet with two growth zones: Sample C04

\section{Garnet composition}

Garnet in $\mathrm{C} 04$ has two distinct growth zones represented by Grt I cores and Grt II rims. They show pronounced compositional zoning where the composition characteristics
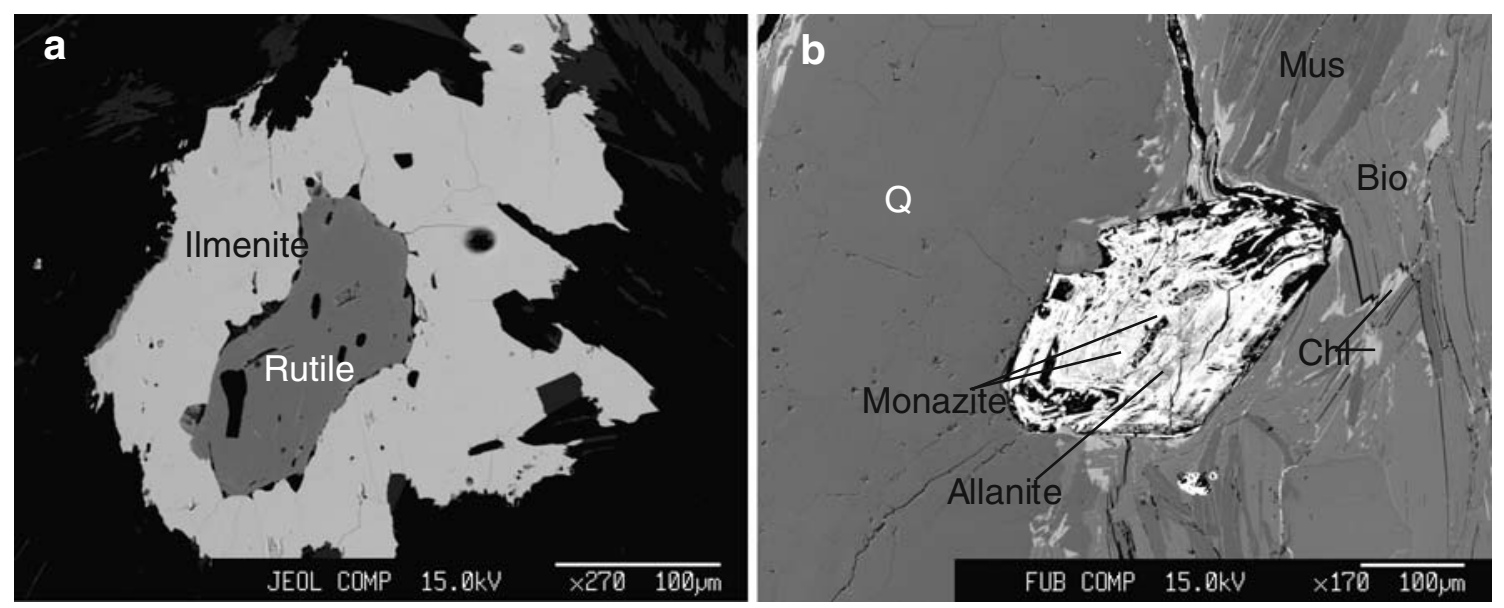

Fig. 3 Back scattered electron (BSE) images of a ilmenite-rutile intergrowth in the matrix, $\mathbf{b}$ relics of monazite grains in allanite in the matrix 
Table 2 Bulk rock compositions as obtained from XRF analyses

\begin{tabular}{llllllllllll}
\hline wt \% & $\mathrm{SiO}_{2}$ & $\mathrm{TiO}_{2}$ & $\mathrm{Al}_{2} \mathrm{O}_{3}$ & $\mathrm{Fe}_{2} \mathrm{O}_{3}$ & $\mathrm{MnO}$ & $\mathrm{MgO}$ & $\mathrm{CaO}$ & $\mathrm{Na}_{2} \mathrm{O}$ & $\mathrm{K}_{2} \mathrm{O}$ & LOI & Total \\
\hline $\mathrm{C} 04$ & 53.60 & 1.19 & 23.40 & 9.73 & 0.12 & 2.55 & 0.46 & 1.75 & 4.28 & 2.80 & 99.88 \\
$\mathrm{C} 05$ & 60.80 & 0.94 & 20.40 & 7.09 & 0.06 & 2.37 & 0.46 & 1.43 & 3.90 & 2.00 & 99.45 \\
$\mathrm{C} 15$ & 52.30 & 1.32 & 24.20 & 9.60 & 0.07 & 3.00 & 0.73 & 1.08 & 4.66 & 2.10 & 99.06 \\
\hline
\end{tabular}

are different for the two growth zones with a sharp compositional discontinuity at the Grt I/Grt II interface (Table 3). The element distribution maps of a central section through the largest garnet that was found from serial sectioning of $\mathrm{C} 04$ are shown in Fig. 4. Quantitative garnet analyses taken along a line profile across this garnet are illustrated in Fig. 5. The radius of Grt $\mathrm{I}$ is about 1.5 millimetres and the thickness of Grt II is about 1 millimetre. Grt I has a sub-idiomorphic shape and shows a relatively uniform distribution of $\mathrm{MgO}$ and $\mathrm{CaO}$ corresponding to pyrope contents of about $\mathrm{X}_{\mathrm{prp}}=0.07$ and grossular contents of about $\mathrm{X}_{\mathrm{grs}}=0.04$. Significant compositional zoning is only observed with respect to the $\mathrm{FeO}$ and $\mathrm{MnO}$ concentrations. Grt I shows a characteristic bell shaped distribution of the Mn-concentrations with the highest spessartine content of about $\mathrm{X}_{\mathrm{sps}}=0.14$ in the centre and as low as $\mathrm{X}_{\mathrm{sps}}=0.05$ at the rims of $\mathrm{Grt} \mathrm{I}$. The $\mathrm{FeO}$ concentrations gradually increase from the core to the rim of Grt I corresponding to contents of $\mathrm{X}_{\mathrm{alm}}=0.75$ in the central portion and $\mathrm{X}_{\mathrm{alm}}=0.80$ in the outermost portion of Grt I.

The transition from Grt I to Grt II is marked by a sharp compositional discontinuity. Grt II started to grow with high $\mathrm{CaO}$ concentrations corresponding to a grossular content of up to $\mathrm{X}_{\mathrm{grs}}=0.25$. The $\mathrm{CaO}$ concentrations decrease rapidly outwards. The grossular content is only about $\mathrm{X}_{\mathrm{grs}}=0.02$ at the outer rims of Grt II. Note that there is a small shoulder in the $\mathrm{CaO}$ profile at about $\mathrm{X}_{\mathrm{grs}}=0.08$ grossular content in the central section of Grt II. This feature is consistent in Grt II from the Wölz Complex and has already been described by Gaidies et al. (2006, 2008b).
Table 3 Selected garnet analyses
Mineral formula for Grt on the basis of 12 oxygens and eight cations

\begin{tabular}{|c|c|c|c|c|c|c|}
\hline \multirow[t]{2}{*}{ Sample } & \multicolumn{3}{|l|}{$\mathrm{C} 04$} & \multicolumn{2}{|l|}{$\mathrm{C} 05 \mathrm{a} 2$} & \multirow{2}{*}{$\begin{array}{l}\text { C15a-2 } \\
\text { Grt I }\end{array}$} \\
\hline & Grt II & $\begin{array}{l}\text { Interface } \\
\text { Grt II/Grt I }\end{array}$ & Grt I & Grt II & Grt I & \\
\hline $\mathrm{SiO} 2$ & 36.70 & 36.87 & 36.87 & 37.87 & 37.38 & 37.27 \\
\hline $\mathrm{Cr} 2 \mathrm{O} 3$ & 0.01 & 0.01 & 0.02 & 0.00 & 0.00 & 0.01 \\
\hline $\mathrm{A} 12 \mathrm{O} 3$ & 20.88 & 21.16 & 20.86 & 21.15 & 21.57 & 21.47 \\
\hline $\mathrm{Fe} 2 \mathrm{O} 3$ & 0.00 & 0.00 & 0.00 & 0.00 & 0.14 & 0.00 \\
\hline $\mathrm{FeO}$ & 35.80 & 31.03 & 31.62 & 30.79 & 35.29 & 32.20 \\
\hline $\mathrm{MnO}$ & 0.16 & 1.52 & 5.96 & 0.29 & 3.98 & 3.16 \\
\hline $\mathrm{NiO}$ & 0.00 & 0.00 & 0.00 & 0.00 & 0.00 & 0.00 \\
\hline $\mathrm{MgO}$ & 2.42 & 1.50 & 1.67 & 3.78 & 1.95 & 1.81 \\
\hline $\mathrm{CaO}$ & 2.52 & 6.87 & 1.82 & 4.63 & 1.49 & 3.78 \\
\hline Total & 98.49 & 98.96 & 98.82 & 98.52 & 101.80 & 99.69 \\
\hline $\mathrm{Si}$ & 3.01 & 2.99 & 3.03 & 3.04 & 2.98 & 3.03 \\
\hline $\mathrm{Cr}$ & 0.00 & 0.00 & 0.00 & 0.00 & 0.00 & 0.00 \\
\hline $\mathrm{Al}$ & 2.02 & 2.02 & 2.02 & 2.01 & 2.03 & 2.03 \\
\hline $\mathrm{Fe} 3+$ & 0.00 & 0.00 & 0.00 & 0.00 & 0.01 & 0.00 \\
\hline $\mathrm{Fe} 2+$ & 2.45 & 2.10 & 2.17 & 2.07 & 2.35 & 2.16 \\
\hline Mn & 0.01 & 0.10 & 0.41 & 0.02 & 0.27 & 0.25 \\
\hline $\mathrm{Ni}$ & 0.00 & 0.00 & 0.00 & 0.00 & 0.00 & 0.00 \\
\hline $\mathrm{Mg}$ & 0.30 & 0.18 & 0.20 & 0.45 & 0.23 & 0.22 \\
\hline $\mathrm{Ca}$ & 0.22 & 0.60 & 0.16 & 0.40 & 0.13 & 0.32 \\
\hline Total & 8.00 & 8.00 & 8.00 & 8.00 & 8.00 & 8.00 \\
\hline pyrope & 0.10 & 0.06 & 0.07 & 0.15 & 0.08 & 0.07 \\
\hline almandine & 0.82 & 0.70 & 0.74 & 0.70 & 0.79 & 0.73 \\
\hline grossular & 0.07 & 0.20 & 0.05 & 0.14 & 0.04 & 0.11 \\
\hline spessartine & 0.00 & 0.04 & 0.14 & 0.01 & 0.09 & 0.08 \\
\hline Total & 1.00 & 1.00 & 1.00 & 1.00 & 1.00 & 1.00 \\
\hline
\end{tabular}


Fig. 4 Element distribution maps from a central section through the largest garnet porphyroblast from sample $\mathrm{C} 04$; the garnet core (Grt I) has subidiomorphic shape and shows a relatively uniform distribution of the $\mathrm{MgO}$ and $\mathrm{CaO}$ concentrations, compositional zoning is only observed with respect to $\mathrm{FeO}$ and $\mathrm{MnO}$ concentrations; the Grt I/Grt II interface is marked by a sharp compositional discontinuity. The first growth increments of Grt II are particularly rich in $\mathrm{CaO}$ and compositional zoning is much more pronounced than in Grt I
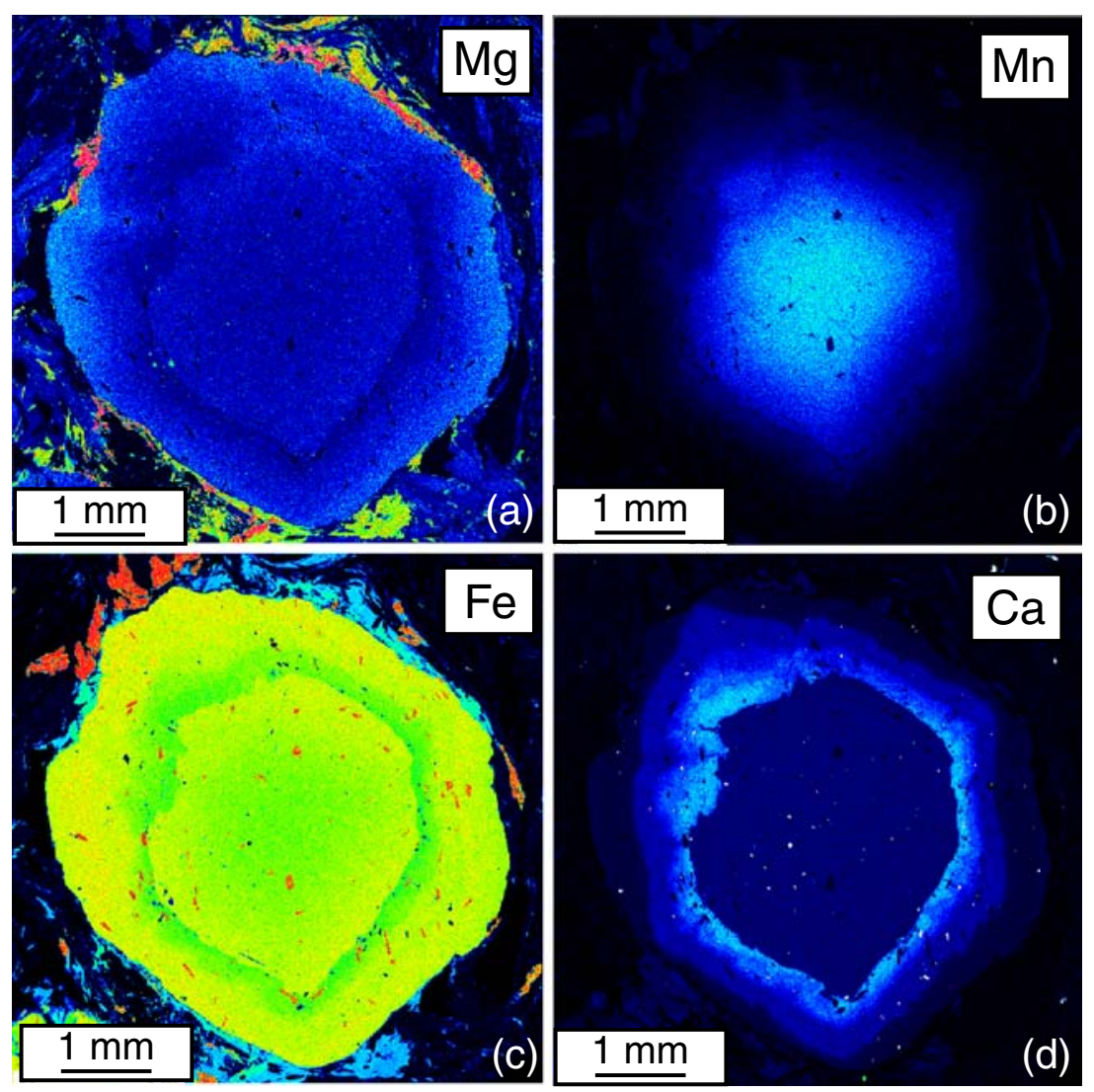

Garnet with a single growth zone: Sample C05

Garnet of the second generation may also occur as porphyroblasts with only one growth zone apart from forming rims around Grt I. Figure 6 shows the compositional zoning of a $5 \mathrm{~mm}$ big garnet porphyroblast with only a single growth zone (Grt II). The zoning is similar to the one observed in Grt II rims from the porphyroblasts with two growth zones. The grossular content decreases from $\mathrm{X}_{\mathrm{grs}}=0.15$ in the core to about $\mathrm{X}_{\mathrm{grs}}=0.02$ in the outermost rim. The pyrope content increases concomitantly from $X_{\text {prp }}=0.10$ in the core region to about $X_{\text {prp }}=0.18$ at the rim. The almandine content varies from $X_{\mathrm{alm}}=0.73$ in the core to $\mathrm{X}_{\mathrm{prp}}=0.84$ in the rims. The spessartine content is generally low at $\mathrm{X}_{\mathrm{sps}}=0.02$ in the centre to $<1$ mole $\%$ in the rim.

\section{Secondary compositional zoning}

Based on the assumption that the primary growth zoning of garnet is concentric and Grt I generally has relatively shallow concentration profiles, deviations from such a pattern are interpreted as modifications of the primary growth zoning and are referred to here as "secondary zoning". Secondary zoning in $\mathrm{Fe}$ and $\mathrm{Mg}$ contents may be induced by re-equilibration between garnet and other $\mathrm{Fe}-$
$\mathrm{Mg}$ bearing phases during cooling yielding retrograde zoning in the outermost garnet, which is typically recognized by an increase in $\mathrm{X}_{\mathrm{Fe}}$ (e.g. Keller et al. 2007 and references therein). Alternatively, secondary zoning may be induced by changes in the chemical environment and metasomatism. In the following we describe several types of secondary zoning that are observed in garnet from the Rappold and Wölz Complexes.

\section{Garnet from sample C15 (Rappold Complex)}

Garnet in C15 has a large Grt I core with a diameter of about $5 \mathrm{~mm}$ and a relatively thin and discontinuous Grt II rim of about $0.2 \mathrm{~mm}$ width. $\mathrm{MgO}$ and $\mathrm{MnO}$ distribution maps and a compositional profile of this garnet are shown in Fig. 7. The porphyroblast was fractured during deformation, and the fracture has been cemented with quartz subsequently.

The $\mathrm{MgO}$ concentrations are relatively low and homogeneously distributed in Grt I and they are comparatively high in Grt II. The MnO concentrations show a typical bell shaped distribution within Grt I, and they are generally low in Grt II.

From the element distribution maps in Fig. 7 it can be seen that over a several $100 \mu \mathrm{m}$ wide zone along the fracture the Mn distribution was altered from the primary 
Fig. 5 Compositional variation across the largest garnet porphyroblast of sample C04;

a BSE image with indication of the position of the line profile; b point analyses along the line profile; dashed vertical lines indicate positions of the Grt I/ Grt II interfaces, numerals above solid vertical lines indicate points at which compositions were used for garnet isopleth thermobarometry (a)

(b)
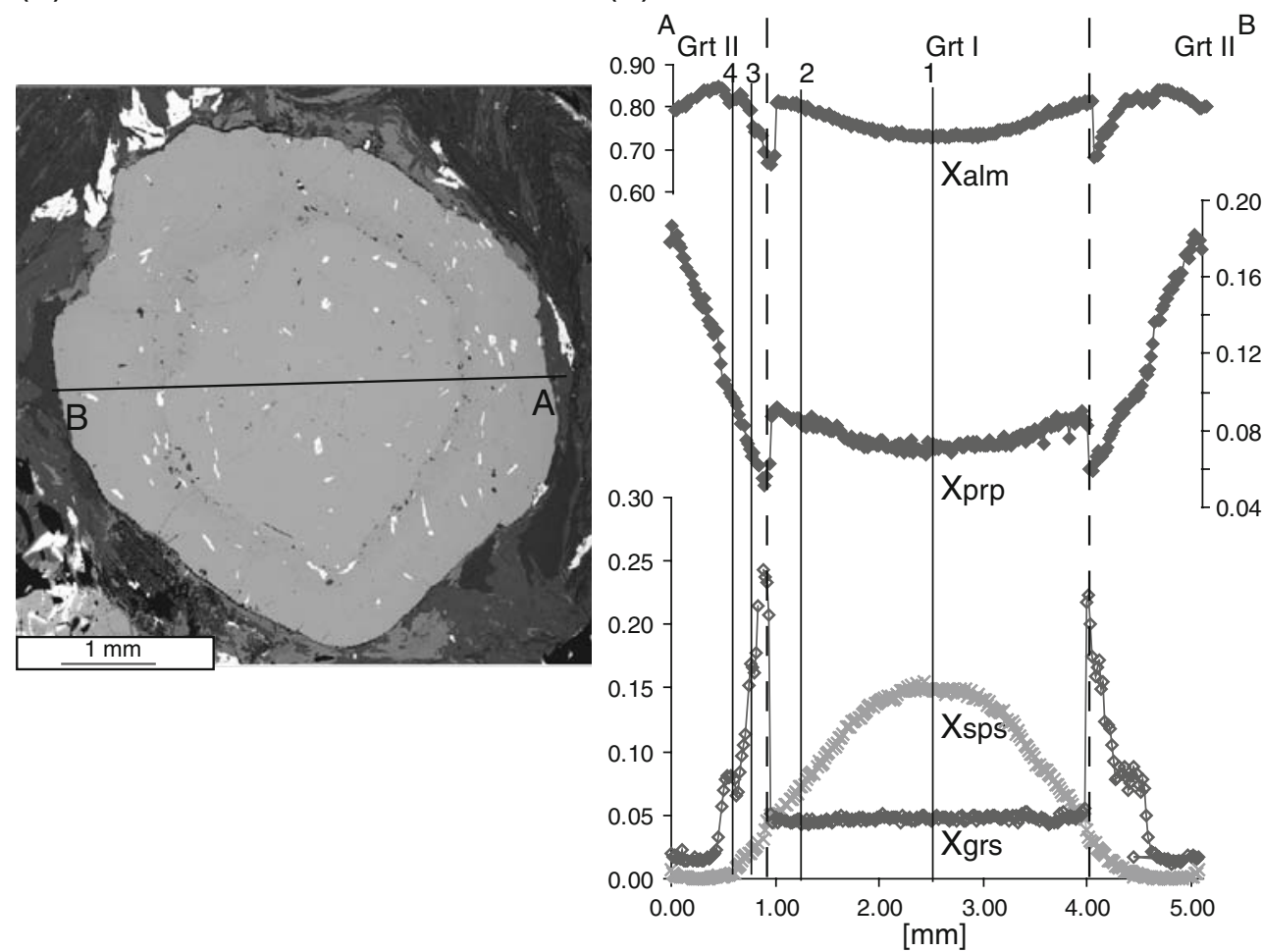

Fig. 6 a $\mathrm{CaO}$ distribution map and $\mathbf{b}$ line profile across the largest garnet porphyroblast with only a single growth zone from sample C05. The compositional zoning is similar to the zoning observed in the Grt II rims form garnet porphyroblasts with two growth zones (a)

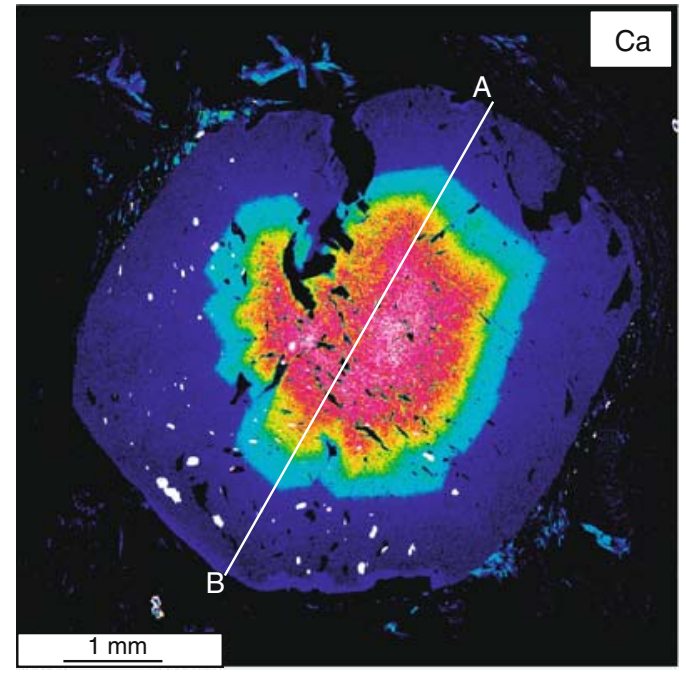

(b)

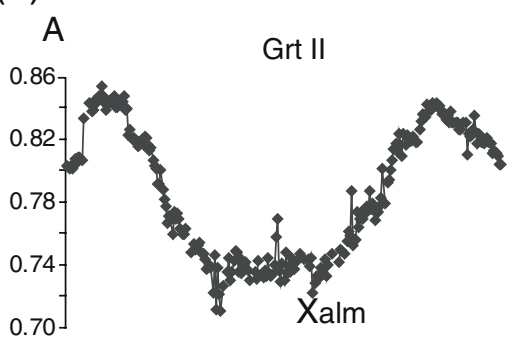

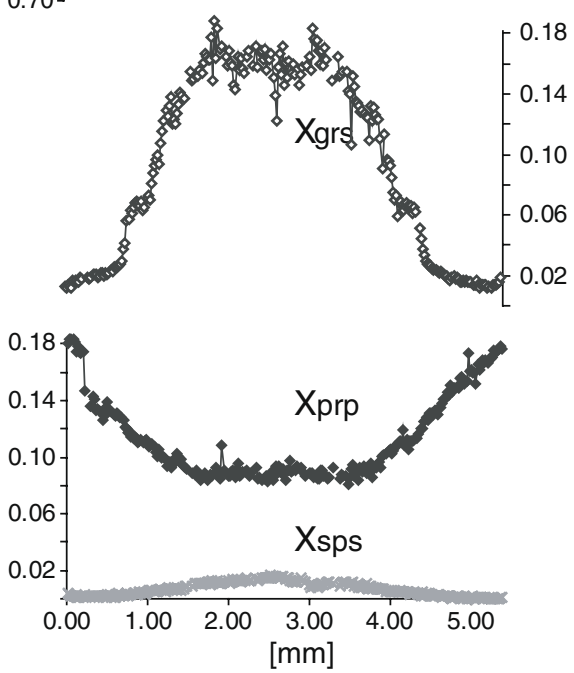


Fig. $7 \mathrm{MgO}$ distribution map a and $\mathrm{MnO}$ distribution map $\mathbf{b}$ of a garnet porphyroblast from sample C15; note the relatively large Grt I core with low $\mathrm{MgO}$ contents, the typical bell shaped $\mathrm{MnO}$ distribution and the relatively thin and discontinuous rim of Grt II with comparatively high $\mathrm{MgO}$ and low $\mathrm{MnO}$ contents; the entire porphyroblast is disrupted along a prominent fracture; note that the garnet composition is modified in the vicinity of the fracture; c quantitative point analyses along the line profile A-B approximately perpendicular to the fracture; note the pronounced $\mathrm{MgO}$ enrichment and $\mathrm{CaO}$ depletion towards the interface with the fracture, dashed lines indicate presumed initial growth zoning
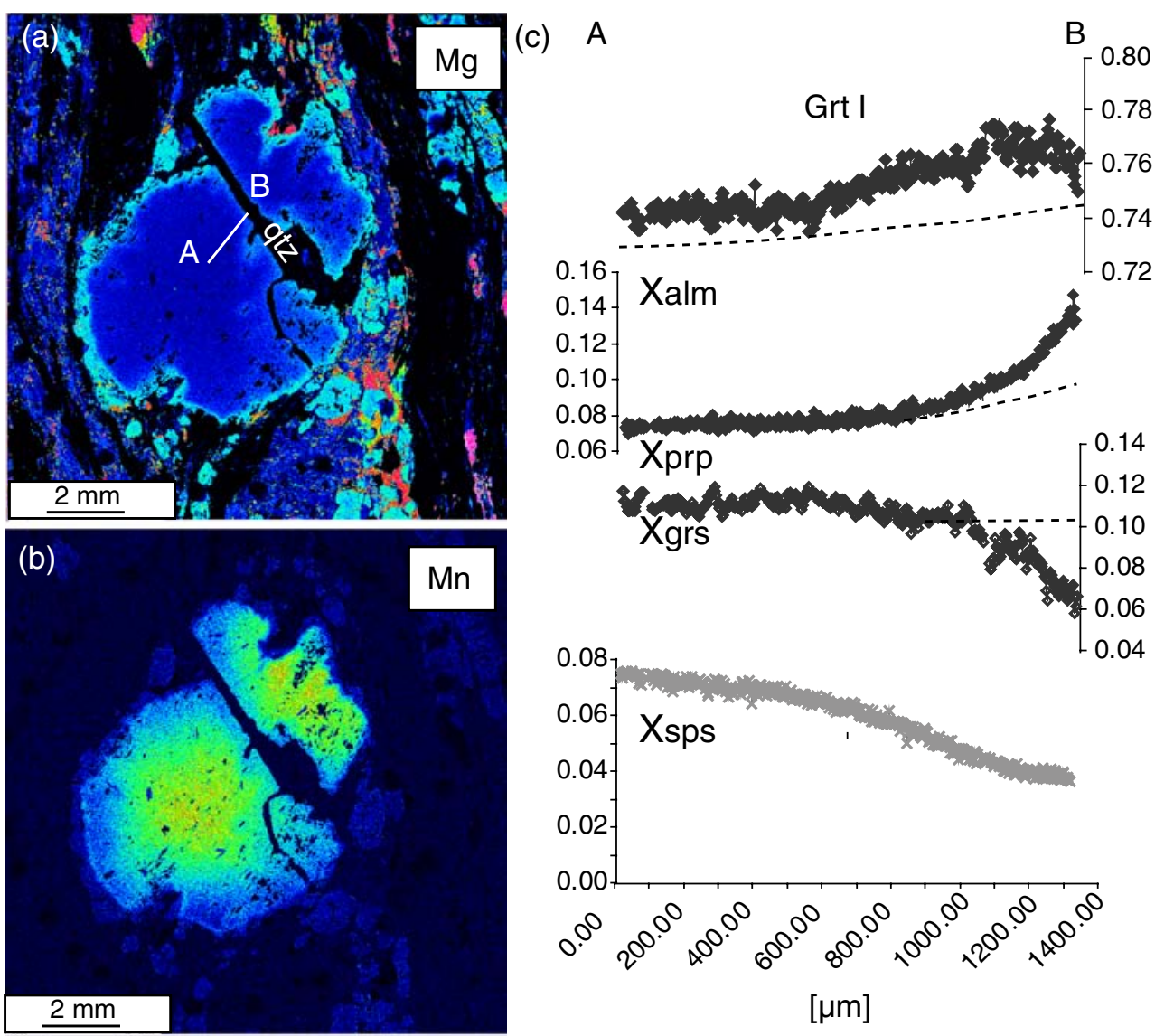

growth zoning which was supposedly concentric. Also the $\mathrm{Mg}$ contents are systematically higher in a narrow zone along the fracture than in the remainder of Grt I. In the detailed profile along the transect $\mathrm{A}-\mathrm{B}$ it is seen that the disrupted fragments of Grt I show a systematic increase in $\mathrm{X}_{\text {prp }}$ and concomitant decrease in $\mathrm{X}_{\mathrm{grs}}$ towards the interface with the quartz filled fracture (see Fig. 7). The iron content shows a complex pattern with a local maximum at about $200 \mu \mathrm{m}$ from the fracture surface, and the Mn content decreases towards the fracture. The overall element distribution and the peculiar chemical variation along the $\mathrm{A}-\mathrm{B}$ transect cannot be explained in terms of a primary growth zoning. They are rather interpreted as a secondary zoning. The gradual compositional changes with a monotonous decrease of the $\mathrm{Ca}$ and $\mathrm{Mn}$ contents and a monotonous increase of the $\mathrm{Mg}$ contents towards the fracture indicate that the supposedly homogeneous initial element distributions were modified by diffusive exchange with the rock matrix across the fracture surface.

It is interesting to note that the alteration effect for $\mathrm{Mg}$ extends further into the garnet than the alteration effect for $\mathrm{Ca}$. Whereas the $\mathrm{Ca}$ concentration reaches its background level corresponding to about $\mathrm{X}_{\mathrm{grs}}=0.11$ at about $300 \mu \mathrm{m}$ from the fracture surface, the $\mathrm{Mg}$ concentration levels out only after about $400 \mu \mathrm{m}$. It is somewhat speculative to estimate the initial $\mathrm{MnO}$ distribution but from the relation between the overall $\mathrm{Mn}$ distribution and the fracture it is inferred that the $\mathrm{Mn}$ distribution was modified to about $700 \mu \mathrm{m}$ from the quartz filled fracture.

\section{Garnet from sample C05 (Wölz Complex)}

Garnet in C05 has two distinct growth zones with a Grt I core of about 1.5 millimetre radius and an about one millimetre wide Grt II rim. Grt I has only few inclusions. In contrast, Grt II has abundant inclusions of quartz, muscovite, paragonite, chlorite, biotite, ilmenite, rutile, tourmaline, apatite and zircon. Based on the element distribution maps in Fig. 8a and b it is seen that the Mg concentrations are significantly higher in Grt II than in Grt I. Within Grt I the Mn concentrations show the typical bell shaped distribution with highest concentrations in the centre and a gradual decrease towards the rim.

With respect to the zoning of the major elements garnet of $\mathrm{C} 05$ is similar to garnet of $\mathrm{C} 04$ described above. Grt I of C05 does, however, show a peculiar feature at the Grt I/Grt II interface and at the phase boundaries to large inclusions. In the outermost 150 to $200 \mu \mathrm{m}$ towards Grt II the $\mathrm{Mg}$ concentrations show a substantial increase corresponding to a shift in composition from $\mathrm{X}_{\mathrm{prp}}=0.08$ which is typical for 
the homogeneous Grt I core to about $\mathrm{X}_{\mathrm{prp}}=0.17$ at the Grt I/ Grt II interface (see traverse A-B). The Ca concentration decreases concomitantly reflecting a shift in composition from about $\mathrm{X}_{\mathrm{grs}}=0.04$ to $\mathrm{X}_{\mathrm{grs}}=0.02$. The Fe concentration decreases from $X_{\text {alm }}=0.78$ to $X_{\text {alm }}=0.76$ towards the interface and the Mn concentrations show a monotonous decrease within Grt I from core to rim. It is difficult to decide to what extent the Mn zoning represents the initial growth zoning and what the influence of late stage alteration was on Mn zoning.

Similar chemical patterns are observed within Grt I in the vicinity of a several $100 \mu \mathrm{m}$ big quartz inclusion (traverse $\mathrm{C}-\mathrm{D}$ in Fig. 8d). The calcium concentrations show a pronounced decrease in the outermost $100 \mu \mathrm{m}$ towards the Grt I/qtz interface representing a compositional change from $\mathrm{X}_{\mathrm{grs}}=0.04$ to 0.02 . The $\mathrm{Mg}$ concentrations show an increase from the supposed background value of $\mathrm{X}_{\mathrm{prp}}=0.07$ at about $300 \mu \mathrm{m}$ from the quartz inclusion to $X_{\text {prp }}=0.15$ at the Grt I/qtz interface. The Fe contents decrease from $X_{\text {alm }}=0.78$ at about $200 \mu \mathrm{m}$ from the fracture to $X_{\mathrm{alm}}=0.77$. $\mathrm{Mn}$ is depleted within Grt I towards the Grt I/qtz interface, and the $\mathrm{Mn}$ iso-concentration contours bend around the quartz inclusion in a several $100 \mu \mathrm{m}$ wide zone along the Grt I/qtz interface. The supposed reference Mn concentrations which are expected along traverse $\mathrm{C}-\mathrm{D}$ for the case that alteration at the Grt I/qtz interface did not occur can be inferred from comparison with the Mn distribution along traverse A-B assuming that the Mn zoning initially was concentric. The inferred reference concentrations of $\mathrm{Mn}$ are indicated as dashed lines in Fig. 8d suggesting that $\mathrm{Mn}$

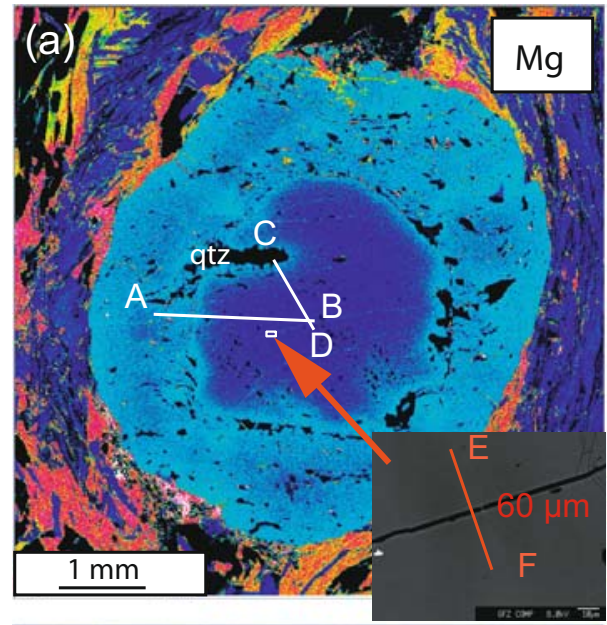

(c)
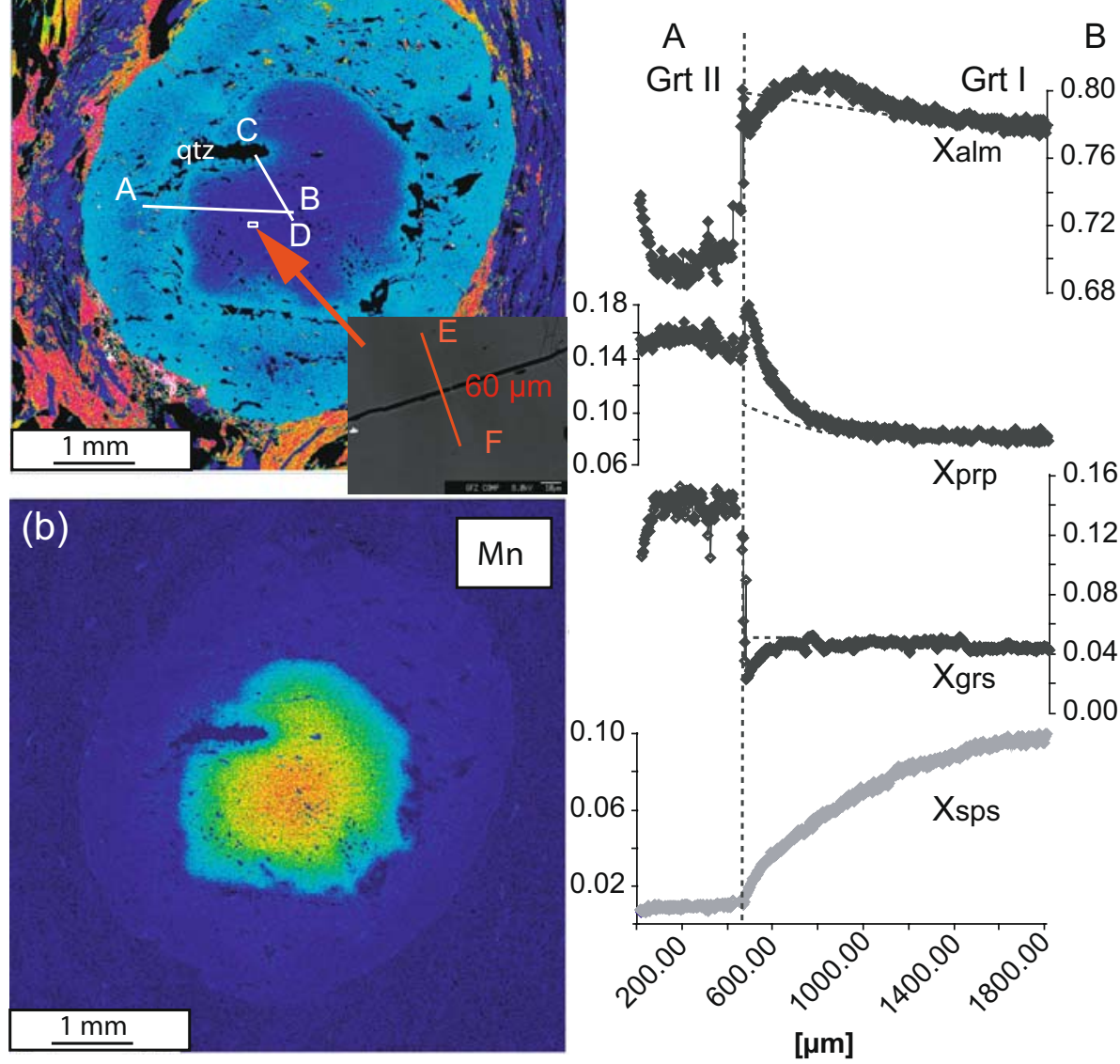

(d)
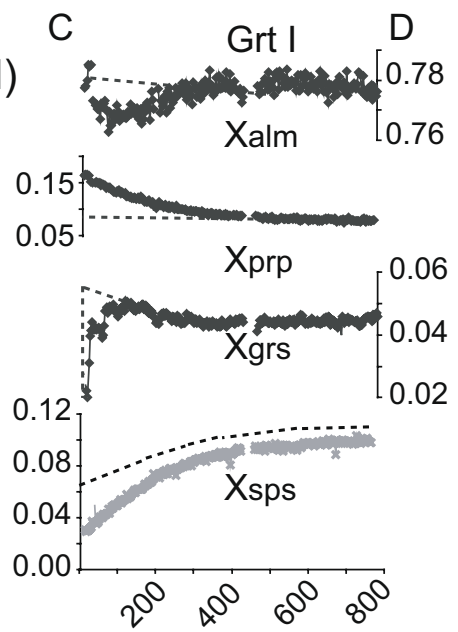

(e)

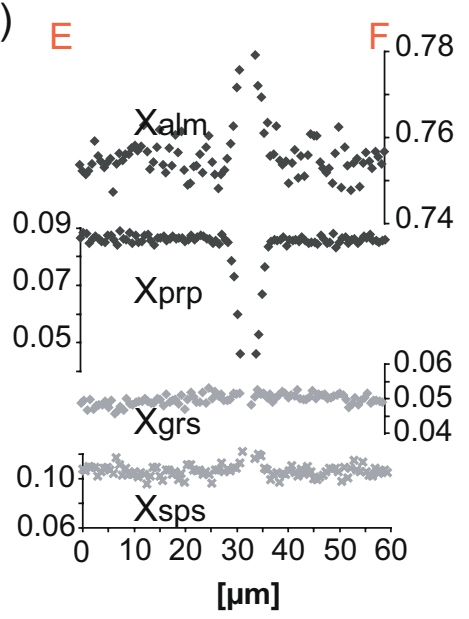

Fig. 8 a $\mathrm{Mg}$ distribution map and $\mathbf{b} \mathrm{Mn}$ distribution map of a garnet porphyroblast from sample $\mathrm{C} 05$; note the relatively low $\mathrm{MgO}$ concentrations in the Grt I core and the comparatively high $\mathrm{MgO}$ concentrations in the Grt II rim; note also the large quartz inclusion in the outermost portion of Grt I, which is rimmed by a zone of elevated $\mathrm{MgO}$ concentrations within Grt I; quantitative garnet analyses taken along traverse $\mathrm{A}-\mathrm{B} \mathbf{c}$ and $\mathrm{C}-\mathrm{D} \mathbf{d}$ reveal pronounced compositional variations within Grt I towards the Grt I/Grt II interface (traverse A-B) and towards the interface between Grt I and the quartz inclusion (traverse $\mathrm{C}-\mathrm{D}$ ); dashed curves in (c) and (d) indicate reference element distribution, which is supposed for the case that alteration at the Grt I/qtz interface did not occur. e small-scale alteration halos around late-stage cracks in Grt I of sample C05; lateral resolution of the FEG-EMS point analyses is better than $500 \mathrm{~nm}$ for $\mathrm{Mg}$ and $\mathrm{Ca}$ and better than $300 \mathrm{~nm}$ for $\mathrm{Fe}$ and $\mathrm{Mn}$ 
concentrations were affected to within about $300 \mu \mathrm{m}$ from the Grt I/qtz interface.

Another alteration phenomenon in garnet from sample C05 is associated with late stage cracks which are well defined within Grt I and are difficult to follow in Grt II where they become rather irregular probably due to interaction with the abundant inclusions (Fig. 8e). Within Grt I a narrow alteration halo is developed around these cracks which is characterized by a pronounced decrease of the $\mathrm{Mg}$ concentrations from $X_{\text {prp }}=0.08$ at more than $5 \mu \mathrm{m}$ from the crack to $\mathrm{X}_{\mathrm{prp}}=0.04$ at the crack surface (see Fig. 10c). This is balanced by a concomitant increase in almandine content from $X_{\text {alm }}=0.76$ in Grt I to 0.78 at the crack surface and an increase in spessartine content from $\mathrm{X}_{\mathrm{sps}}=0.11$ to 0.13 . The grossular content does not change towards the crack surface.

Thermodynamic modelling

\section{Pseudosection calculation}

Pseudosections were calculated using the PERPLEX program package (Connolly 1990; Connolly and Petrini 2002) in the simplified model system $\mathrm{SiO}_{2}, \mathrm{Al}_{2} \mathrm{O}_{3}, \mathrm{MgO}$, $\mathrm{FeO}, \mathrm{CaO}, \mathrm{MnO}, \mathrm{K}_{2} \mathrm{O}, \mathrm{H}_{2} \mathrm{O}$ for the bulk rock compositions of sample $\mathrm{C} 04$. The system was considered saturated with respect to quartz and water. Thermodynamic data were taken from Holland and Powell (1998) (update 2002) and the following solid solutions were used: Bio (biotite, $\mathrm{K}\left(\mathrm{Mg}_{\mathrm{x}} ; \mathrm{Fe}_{\mathrm{y}} ; \mathrm{Mn}_{1-\mathrm{x}-\mathrm{y}}\right)_{3-\mathrm{w}}\left(\mathrm{Al}_{1+2 \mathrm{w}} \mathrm{Si}_{3-\mathrm{w}} \mathrm{O}_{10}(\mathrm{OH})_{2}\right)$, Grt (garnet, $\mathrm{Fe}_{3 \mathrm{x}} \mathrm{Ca}_{3 \mathrm{y}} \mathrm{Mg}_{3 \mathrm{z}} \mathrm{Mn}_{3(1-\mathrm{x}-\mathrm{y}-\mathrm{z})} \mathrm{Al}_{2} \mathrm{Si}_{3} \mathrm{O}_{12}$ ), Chl (chlorite, $\left.\mathrm{Mg}_{\mathrm{x}} \mathrm{Fe}_{\mathrm{w}} \mathrm{Mn}_{(1-\mathrm{x}-\mathrm{w}) 5-\mathrm{x}-\mathrm{w}} \mathrm{Al}_{2(1+\mathrm{y}-\mathrm{z})} \mathrm{Si}_{3-\mathrm{y}+\mathrm{z}} \mathrm{O}(\mathrm{OH})_{8}\right)$, Pheng (phengite, $\mathrm{K}_{\mathrm{x}} \mathrm{Na}_{1-\mathrm{x}} \mathrm{Mg}_{\mathrm{y}} \mathrm{Fe}_{\mathrm{z}} \mathrm{Al}_{3-2(\mathrm{y}+\mathrm{z})} \mathrm{Si}_{3+\mathrm{y}+\mathrm{z}} \mathrm{O}_{10}(\mathrm{OH})_{2}$ ), St (staurolite, $\mathrm{Mg}_{4 \mathrm{x}} \mathrm{Fe}_{4 \mathrm{y}} \mathrm{Mn}_{4(1-\mathrm{x}-\mathrm{y})} \mathrm{Al}_{18} \mathrm{Si}_{7.5} \mathrm{O}_{48} \mathrm{H}_{4}$ ), Ctd (chloritoid, $\mathrm{Mg}_{\mathrm{x}} \mathrm{Fe}_{\mathrm{y}} \mathrm{Mn}_{1-\mathrm{x}-\mathrm{y}} \mathrm{Al}_{2} \mathrm{SiO}_{5}(\mathrm{OH})_{2}$ ), feldspar $\left.\left(\mathrm{Na}_{\mathrm{x}} \mathrm{K}_{1-\mathrm{x}}\right)_{\mathrm{y}} \mathrm{Ca}_{1-\mathrm{y}} \mathrm{Al}_{2-\mathrm{y}} \mathrm{Si}_{2+\mathrm{y}} \mathrm{O}_{8}\right)$ and IlGkPy (ilmenitegeikielite-pyrophanite, $\mathrm{Mg}_{\mathrm{x}} \mathrm{Mn}_{\mathrm{y}} \mathrm{Fe}_{1-\mathrm{x}-\mathrm{y}} \mathrm{TiO}_{3}$ ).

A pseudosection that was calculated for the bulk rock composition of $\mathrm{C} 04$ is shown in Fig. 9a. It can be seen that the garnet stability field extends from about $530^{\circ} \mathrm{C}$ and $350 \mathrm{MPa}$ to higher pressures and temperatures. At the lower limit of the garnet stability field $\left(\mathrm{T}=530-560^{\circ} \mathrm{C}, \mathrm{P}=350\right.$ $450 \mathrm{MPa}$ ) garnet coexists with chlorite, biotite, phengite, ilmenite, quartz, feldspar and staurolite. At higher temperatures chlorite and staurolite are unstable and sillimanite appears. In the divariant fields expanding from $540^{\circ} \mathrm{C}$ to higher temperature and $550 \mathrm{MPa}$ to higher pressure conditions garnet coexists with biotite, chlorite, phengite, staurolite, feldspar, paragonite, quartz and ilmenite. At lower temperatures biotite and staurolite are unstable and zoisite coexists with garnet. (a)

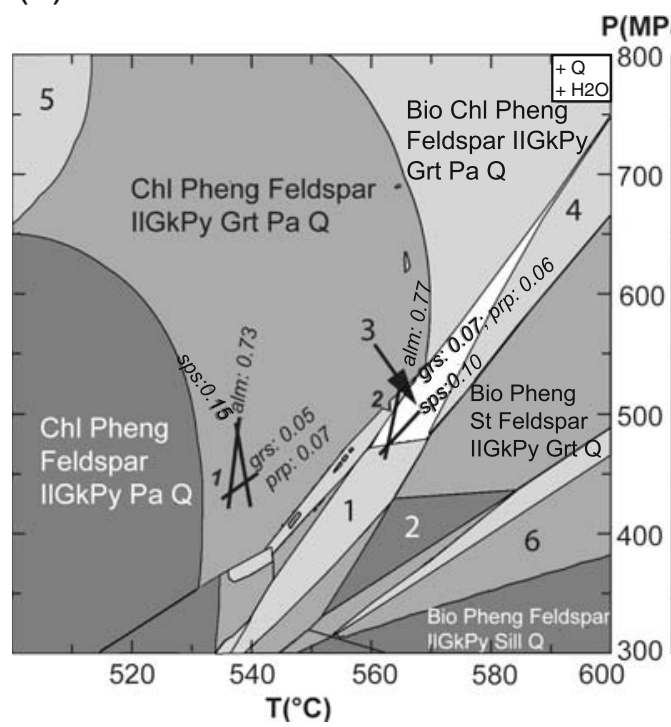

Fig. 9 a Pseudosection calculated for bulk rock composition of sample $\mathrm{C} 04$ (Table 2) with $\mathrm{H}_{2} \mathrm{O}$ and quartz saturation. Stability fields are labelled with stable phases, Q: quartz, Bio: biotite, Chl: chlorite, IlGkPy: ilmenite-geikielite-pyrophanite, Grt: garnet, Pheng: phengite, St: staurolite, Pa: paragonite, Sill: sillimanite. (1) Bio Chl Pheng St Feldspar IlGkPy Grt Q, (2) Bio Pheng St Feldspar IlGkPy Q, (3) Bio Chl Pheng St Feldspar IlGkPy Grt Pa, (4) Bio Pheng St Feldspar IlGkPy Grt Pa Q, (5) Chl Pheng Feldspar IlGkPy Grt Zo Pa Q, (6) Bio Pheng Feldspar IlGkPy Grt Sill Q, (7) Bio Chl Pheng St feldspar (b)

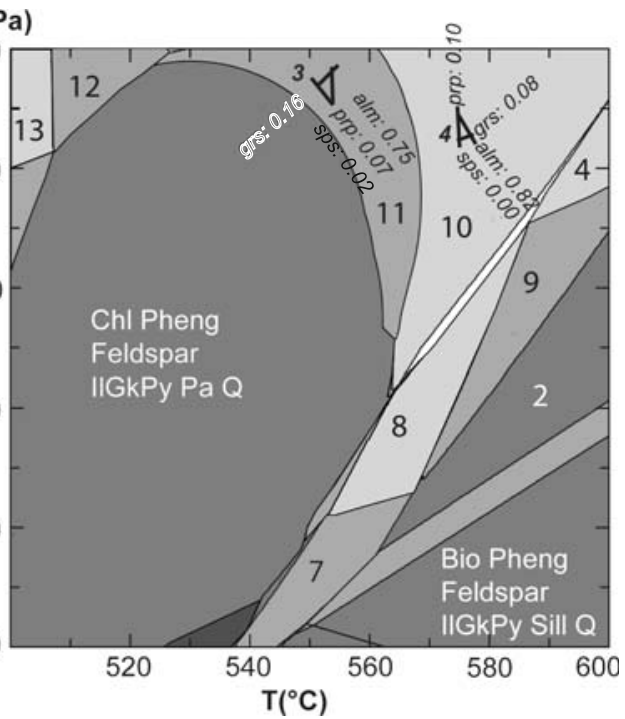

IlGkPy Q, (8) Bio Chl Pheng St Feldspar IlGkPy Pa Q, (9) Bio Pheng St Feldspar IlGkPy Pa Q, (10) Bio Chl Pheng Feldspar IlGkPy Grt Pa Q, (11) Chl Pheng Feldspar IlGkPy Grt Pa Q, (12) Chl Pheng Feldspar IlGkPy Zo Pa Q, (13) Chl Pheng feldspar IlGkPy Zo Pa Ru Q. b Pseudosection calculated for bulk rock composition considering chemical fractionation of Grt I (sample C04). Garnet is stable at temperatures above about $530^{\circ} \mathrm{C}$ and pressures in excess of $350 \mathrm{MPa}$. The calculated garnet isopleth intersections in $\mathbf{a}$ and $\mathbf{b}$ correspond to the observed garnet composition (points $1-4$ in Fig. 5) 


\section{Garnet isopleth thermobarometry}

Garnet isopleth thermobarometry (e.g. Spear and Selverstone 1983; Vance and Holland 1993; Gaidies et al. 2006) was used to estimate the $\mathrm{P}-\mathrm{T}$ conditions during garnet growth. The inherent assumptions of growth of garnet in equilibrium with the matrix and preservation of the original growth zoning seem to be justified for garnet of $\mathrm{C} 04$ from the petrographic evidence presented above. Only those portions of the garnet porphyroblast that have been affected by late stage compositional change must be avoided when using this technique.

It must be noted that for a given bulk rock composition and $\mathrm{P}-\mathrm{T}$ evolution the zoning pattern of a garnet porphyroblast depends on the time of nucleation and on nearest neighbour distance. To account for these effects an entire garnet population needs to be analyzed with respect to grain size distribution, spatial distribution and chemical zoning (Carlson 1991; Gaidies et al. 2008a). Such an analysis is very time consuming and computationally expensive and cannot be done on a routine basis. To minimize the effects that may arise from a complex nucleation history and interaction between neighbouring porphyroblasts the largest garnet porphyroblast found by serial sectioning at $1 \mathrm{~mm}$ intervals in a rock volume of $1 \times 2 \times 3 \mathrm{~cm}$ of sample C04 was selected for analysis.

When garnet isopleth thermobarometry is applied to successive growth increments of a porphyroblast the fractionation effect, which arises from preferential partitioning of for example $\mathrm{Mn}$ and $\mathrm{Ca}$ into garnet, needs to be accounted for (Gaidies et al. 2006). This is done by incrementally changing $\mathrm{P}$ and $\mathrm{T}$ along a prescribed $\mathrm{P}-\mathrm{T}$ path. If garnet is formed during such an incremental step it is removed from the system immediately and the bulk composition of the remaining system is adapted accordingly. This accounts for the fact that due to the refractory nature of garnet the components that are partitioned into garnet are effectively removed from the system. These components are then no longer "available" and must not be considered for phase equilibria in the remainder of the system. For fractionation from point 1 to 2 in Grt I an isobaric path at $500 \mathrm{MPa}$ was used; fractionation from point 3 to 4 was calculated isobarically at $750 \mathrm{MPa}$. Figure 9 shows the results of garnet isopleth thermobarometry for sample C04. The isopleth intersections of compositional contours of Grt I at points 1 and 2 in traverse A-B of Fig. 5 plot at relatively low pressure of about 400 to $500 \mathrm{MPa}$ and temperatures in the range of 540 to $560^{\circ} \mathrm{C}$. This is in line with results of Gaidies et al. (2006) who estimated P-T conditions during growth of Grt I at 535 to $555^{\circ} \mathrm{C}$ and 400 to $450 \mathrm{MPa}$ based on garnet isopleth thermobarometry on samples from the Wölz Complex. This finding is also in line with the pressure estimate of Schuster et al. (2004), which is based on the presence of margarite as inclusion in Grt I from the Wölz Complex. The low-pressure conditions are ascribed to the Permian event of metamorphism that was dated at $269 \pm 4 \mathrm{Ma}$ by Schuster and Thöni (1996).

The isopleths, which represent compositions of Grt II at points 3 and 4 in traverse A-B of Fig. 5, plot at substantially higher pressures in the range of 700 to $800 \mathrm{MPa}$ and at temperatures ranging from 550 to $570^{\circ} \mathrm{C}$ (Fig. 9). This is again compatible with the inferences of Gaidies et al. (2006), who derived conditions of 650 to $700 \mathrm{MPa}$ and 540 to $550^{\circ} \mathrm{C}$ for the period of Grt II formation. This second garnet generation is ascribed to the Eo-Alpine metamorphic overprint that was associated with continent-continent collision during the Cretaceous. The peak of this second metamorphic event has been dated at 92 Ma very consistently in several positions of the Austroalpine basement (e.g. Thöni 2006). It is argued by the latter author that Eo-Alpine metamorphism is very short lived and most of the units were exhumed from eclogite and amphibolite facies conditions to lower greenschist facies conditions at temperatures of $300^{\circ} \mathrm{C}$ or less within less than 10 Ma. Faryad and Chakraborty (2005) also argue for fast subduction and subsequent exhumation based on the analysis of diffusion profiles at Grt I/Grt II interfaces. Finally the preservation of subtle and small-scale compositional zoning patterns in Grt II also corroborates the short-lived nature of Eo-Alpine metamorphism (Gaidies et al. 2008b; Prenzel et al. 2009).

\section{Diffusion modelling}

The compositional zoning within Grt I at Grt I/Grt II interfaces and at the interfaces of Grt I with quartz inclusions or with a quartz filled fracture (Figs. 7 and 8) are believed to reflect compositional alteration of the preexisting garnet, that is, secondary zoning. We model the scenario that alteration of the pre-existing Grt I occurred by diffusion-controlled exchange with the rock matrix or with Grt II overgrowth. We fit model curves to the measured composition profiles in order to constrain the duration of this exchange.

In our model we consider inter-diffusion of the substitutional components $\mathrm{Ca}^{2+}, \mathrm{Mg}^{2+}, \mathrm{Fe}^{2+}$ and $\mathrm{Mn}^{2+}$. The diffusive fluxes of $\mathrm{Ca}^{2+}, \mathrm{Mg}^{2+}, \mathrm{Fe}^{2+}$ are treated as independent and the flux of $\mathrm{Mn}^{2+}$ as dependent. For the one-dimensional case at hand Ficks second law may be written as

$$
\frac{d}{d t}\left(\begin{array}{c}
c_{C a} \\
c_{M g} \\
c_{F e}
\end{array}\right)=\frac{d}{d x}\left[\left(\begin{array}{ccc}
D_{C a C a} & D_{C a M g} & D_{C a F e} \\
D_{M g C a} & D_{M g M g} & D_{M g F e} \\
D_{F e C a} & D_{F e M g} & D_{F e F e}
\end{array}\right) \cdot\left(\begin{array}{c}
\frac{d c_{C a}}{d x} \\
\frac{d c_{M g}}{d x} \\
\frac{d c_{F e}}{d x}
\end{array}\right)\right]
$$

The diffusion equation is solved numerically using an implicit finite difference scheme taken from Keller et al. 
(2006). The inter-diffusion coefficients were calculated from self-diffusion coefficients using the relation of Lasaga (1979):

$D_{i j}=D_{i}^{*} \delta_{i j}-\frac{z_{i} c_{i} D_{i}^{*}}{\sum_{k=1}^{n} z_{k}^{2} c_{k} D_{k}^{*}} z_{j}\left(D_{i}^{*}-D_{n}^{*}\right)$,

where $\mathrm{D}_{\mathrm{i}}^{*}$ is the tracer diffusion coefficient of the $\mathrm{i}^{\prime}$ th component and $\delta_{i j}=0$ if $\mathrm{i} \neq \mathrm{j}$, and 1 if $\mathrm{i}=\mathrm{j} . \mathrm{z}_{\mathrm{i}}$ is the electrical charge of the $i^{\prime}$ th component and component $n$ is the dependant component. The tracer diffusion coefficients are calculated from the Arrhenius relation

$D_{i}^{*}=A_{0} \exp \left(-\frac{E_{A}+P V_{A}}{R T}\right)$,

where $A_{0}$ is the frequency factor, $E_{A}$ is the activation energy and $\mathrm{V}_{\mathrm{A}}$ is the activation volume; $\mathrm{R}=8.314 \mathrm{~J} \mathrm{~mol}^{-1} \mathrm{~K}^{-1}$ and $\mathrm{T}$ is absolute temperature. The $\mathrm{A}_{0}, \mathrm{E}_{\mathrm{A}}$ and $\mathrm{V}_{\mathrm{A}}$ parameters were taken from Chakraborty and Ganguly (1992) and are given in Table 4.

It is not clear beforehand from petrographic evidence when the secondary zoning of Grt I was developed. The secondary zoning might have been produced during diffusion-controlled exchange of Grt I with either the rock matrix, if chemical alteration occurred before Grt II was formed, and/or \pm contemporaneously with Grt II, if chemical alteration occurred during or after the growth of Grt II. In this respect it is important to distinguish between alteration phenomena that extend several $100 \mu \mathrm{m}$ into Grt I and small-scale alteration phenomena which are restricted to a narrow zone of several 10 's of $\mu \mathrm{m}$ in the outermost Grt I at its interface to Grt II.

Let us first consider the secondary zoning of Grt I towards the quartz filled fracture in $\mathrm{C} 15$. In this case the scenario of diffusion exchange between Grt I and Grt II can be excluded because there is no Grt II overgrowth on the fracture surface. The lack of Grt II overgrowth on the fracture surface does not allow, however, the conclusion that fracturing postdates Grt II growth. Grt I in C15 is probably of Variscan age. Hence, fracturing may have occurred at a late stage of the Variscan evolution, during high-temperature/low-pressure overprint in the Permian, or during Eo-Alpine deformation. Irrespective of the timing, the inferred alteration extends several $100 \mu \mathrm{m}$ into

Table 4 Parameters of the Arrhenius equation used for calculation of the tracer diffusion coefficients taken from Chakraborty and Ganguly (1992)

\begin{tabular}{lccc}
\hline & $\mathrm{A}_{0}[\mathrm{~m} 2 / \mathrm{s}]$ & $\mathrm{E}_{\mathrm{A}}[\mathrm{J} / \mathrm{mol})$ & $\mathrm{V}_{\mathrm{A}}\left[\mathrm{cm}^{3} / \mathrm{mol}\right]$ \\
\hline $\mathrm{D}_{\mathrm{Fe}}$ & $6.4 * 10^{-8}$ & 275408 & 0.56 \\
$\mathrm{D}_{\mathrm{Mg}}$ & $1.1 * 10^{-7}$ & 284499 & 0.53 \\
$\mathrm{D}_{\mathrm{Mn}}$ & $5.1 * 10^{-8}$ & 253421 & 0.60 \\
$\mathrm{D}_{\mathrm{Ca}}=0.5 \mathrm{D}_{\mathrm{Fe}}$ & & & \\
\hline
\end{tabular}

Grt I and shows a consistent trend of decreasing $\mathrm{X}_{\text {grs }}$ and $\mathrm{X}_{\mathrm{sps}}$ and an increase in $X_{\text {prp }}$ from the interior of Grt I towards the fracture surface. The almandine content shows a more complex behaviour with a local maximum some $200 \mu \mathrm{m}$ inwards from the fracture surface. These trends are similar to what is seen on the scale of about $400 \mu \mathrm{m}$ also at the Grt I/ Grt II interface in C05. The fact that the alteration effects are similar at the interface of Grt I with a quartz-filled fracture and at Grt I/Grt II interfaces suggests that the several hundred- $\mu \mathrm{m}$-wide alteration haloes were produced by exchange with the rock matrix probably before the onset of Grt II growth. Only a second generation of alteration phenomena, which is identified in Grt I within an about $50 \mu \mathrm{m}$ wide zone at the interface to Grt II in sample C05 appears to be related to diffusion exchange between Grt I and Grt II.

Chemical alteration of Grt I at Grt I/Grt II interfaces was also observed by Faryad and Chakraborty (2005). These latter authors interpreted the chemical alteration in Grt I as an effect of diffusion-controlled $\mathrm{Ca}-\mathrm{Mg}-\mathrm{Fe}-\mathrm{Mn}$ exchange between Grt I and Grt II. In their model, Grt I and Grt II are considered a diffusion couple and constraints on the timing of Eo-Alpine metamorphism are derived from fitting model curves to the observed zoning patterns. We address the first generation of alteration effects from a different perspective which is motivated by the fact that alteration of Grt I does not only occur at Grt I/Grt II interfaces but is equally developed at Grt I/quartz interfaces. This latter case cannot be modelled in terms of a one dimensional diffusion couple where chemical shifts in Grt I can be balanced by complementary shifts in Grt II. From our petrographic observations we rather infer that alteration of the outermost several $100 \mu \mathrm{m}$ of Grt I is due to exchange of the preexisting garnet with some transport medium which was present at stages of elevated temperature at the outer limits of Grt I and at the interfaces to large quartz inclusion or quartz filled cracks. We do not see any complementary compositional shifts that would identify the sources and sinks for the material gains and losses that are associated with the observed alteration of Grt I. This is why we model the observed alteration using prescribed concentrations, i.e. Dirichlet boundary conditions at the outer limits of Grt I. It is well possible that the composition of the transport medium at the outer limits of Grt I changed during chemical alteration. Given the lack of knowledge on such an evolution we refer to the simplest possible assumption of constant concentration where the present day composition of Grt I at its outer limit is assumed to represent the corresponding equilibrium composition of garnet in contact with the rock matrix.

In our model we assume that exchange occurred during the high temperature stages of the polymetamorphic evolution. For sample C15 the thermal peak of Variscan and possibly also of Eo-Alpine metamorphism was probably at about $620^{\circ} \mathrm{C}$. For sample $\mathrm{C} 05$ the thermal peak was 
at about $610^{\circ} \mathrm{C}$ in the Permian and at about $600^{\circ} \mathrm{C}$ during the Eo-Alpine evolution (Faryad and Hoinkes 2003; Gaidies et al. 2008b). In diffusion modelling we assume that exchange starts at about $560^{\circ} \mathrm{C}$ and is active during passage of the rocks through the thermal peak and ceases when the rock is cooled to below $560^{\circ} \mathrm{C}$ after the thermal peak. Given the lack of knowledge of the exact T-t trajectory we assume a parabolic shape of the T-t trajectory.

A comparison between model predictions and observed alteration trends in $\mathrm{C} 05$ and $\mathrm{C} 15$ is shown in Fig. 10. For alteration of Grt I at the interface to the qtz-filled fracture in C15 we obtain a satisfactory agreement between model prediction and the observed alteration trend if alteration is allowed to occur in the temperature interval of 570 to $620^{\circ} \mathrm{C}$ where the duration of this high-temperature stage is on the order of $20 \mathrm{Ma}$ (Fig. 10a). It is known from independent geochronological constraints that Eo-Alpine metamorphism was a very short-lived event. Peak pressures and temperatures were reached at about $92 \mathrm{Ma}$ and the rocks were at temperatures of about $300^{\circ} \mathrm{C}$ at $80 \mathrm{Ma}$ (Thöni 2006). This

Fig. 10 Comparison of model curves with observed garnet compositions, $\mathbf{a}$ in Grt I of sample $\mathrm{C} 15$ towards its interface with the quartz-filled fracture, profile A-B in Fig. 7; solid line: model curve, dashed line: supposed initial conditions; $\mathbf{b}$ at $\mathrm{Grt}$ $\mathrm{I} / \mathrm{Grt}$ II interface in sample $\mathrm{C} 05$, traverse A-B in Fig. 8; $\mathbf{c}$ at the fracture in Grt I, traverse $\mathrm{E}-\mathrm{F}$ in Fig. 8 (sample C05). The diagrams at the bottom indicate the $\mathrm{T}-\mathrm{t}$ trajectories considered in diffusion modelling (a)
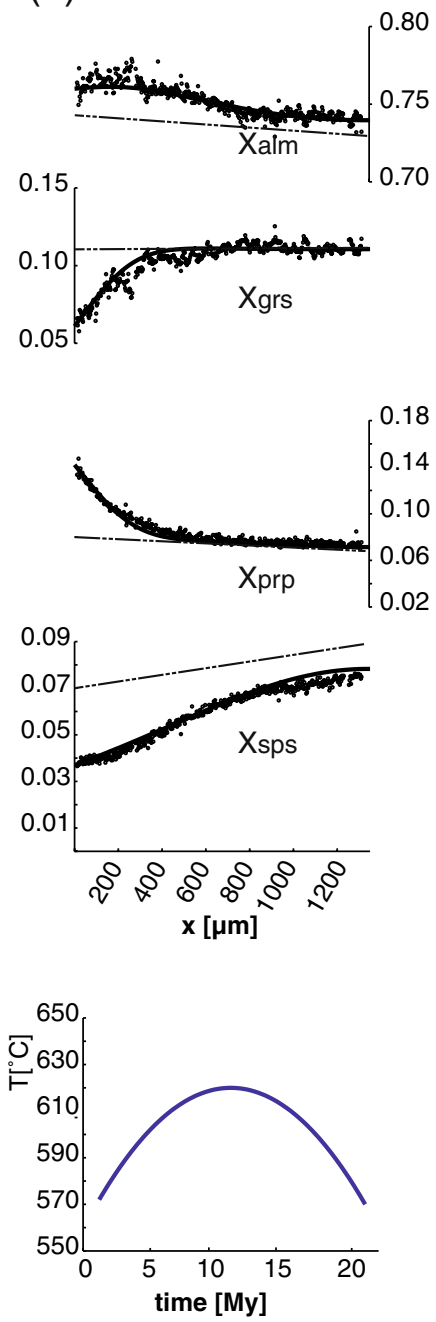

makes it unlikely that the several $100 \mu \mathrm{m}$ wide alteration halos in Grt I of C15 were produced during the Eo-Alpine event. It rather points to the high-temperature stages of the Variscan and the Permian metamorphic cycles as potential episodes of diffusion exchange.

For the alteration effects at the Grt I/Grt II interface of C05 we obtain the best fit between model and observed alteration phenomena if we allow exchange to occur throughout a high-temperature stage in the temperature interval of 570 to $610^{\circ} \mathrm{C}$ where the rocks remained in this temperature interval over $10 \mathrm{Ma}$, still implying the parabolic T-t trajectory (Fig. 10b). Grt I of C05 is probably of Permian age. Therefore, the secondary zoning in the outermost several hundred $\mu \mathrm{m}$ of Grt I might have been developed during late stages of Permian metamorphism after growth of Grt I ceased. It is likely that garnet growth ceased before the thermal peak of metamorphism was reached so that it was present in its entirety throughout a large portion of the high-temperature stage of the Permian event. The fact that the timescale derived from the (b)
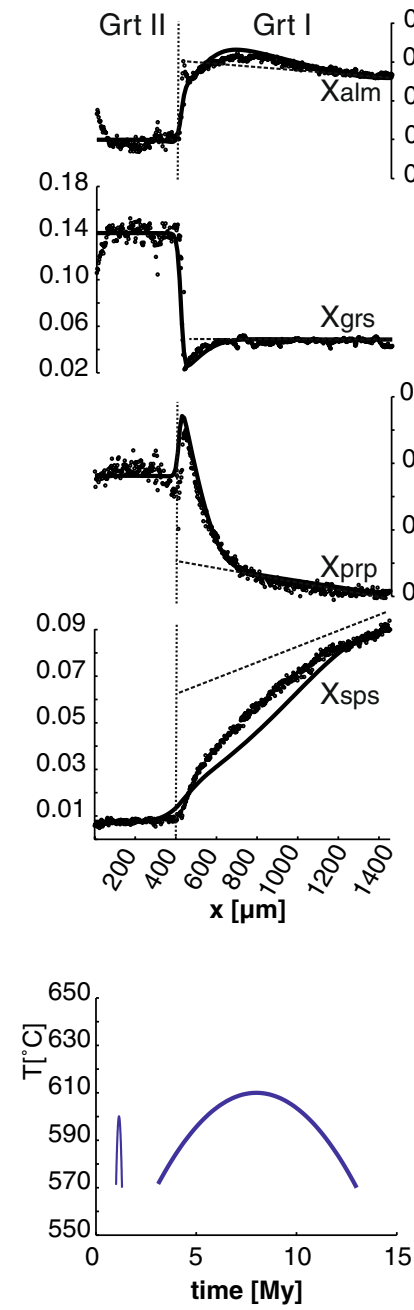

(c)
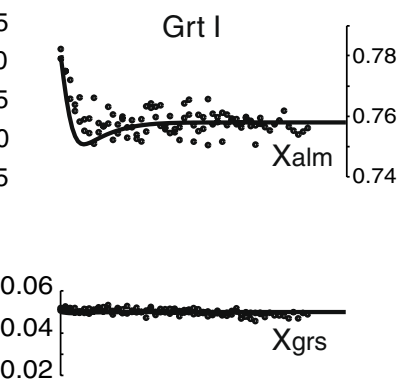

0.20

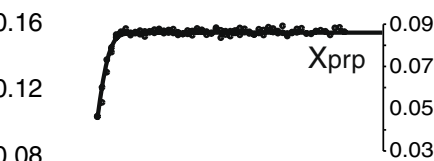

0.08 0.03
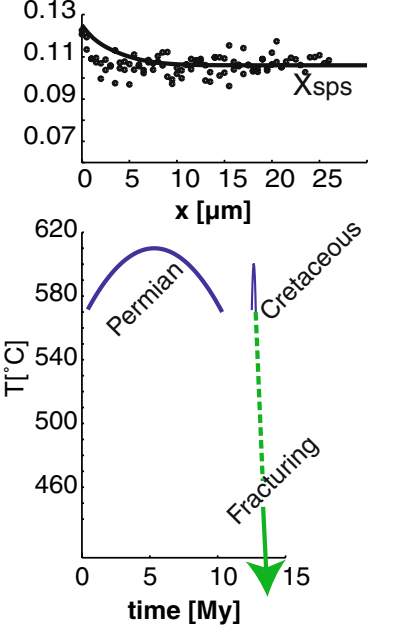
alteration profile of $\mathrm{C} 05$ is by a factor of 2 shorter than the one derived from $\mathrm{C} 15$ possibly indicates that fracturing of Grt I in C15 already occurred during the Variscan and that Grt I was subject to exchange with the matrix at the fracture surface throughout the entire Permian evolution. Grt I in C05 might have been altered by diffusion exchange only during the late stage of the Permian evolution. Alternatively this difference in inferred time scales may reflect slightly higher peak temperatures in the Rappold Complex (sample C15) as compared to the Wölz Complex (sample C05) during the Permian event.

In $\mathrm{C} 05$ the second generation of alteration phenomena is represented by a rapid drop in $X_{\text {prp }}$ in the outermost $50 \mu \mathrm{m}$ of Grt I at the interface towards Grt II and by a concomitant increase of $X_{\text {grs }}$ in the outermost $30 \mu \mathrm{m}$ of Grt I. It is modelled considering diffusion-controlled exchange between Grt I and Grt II. For the initial conditions in Grt I the model curves obtained from modelling the Permian cycle were used. Grt II was taken as compositionally homogenous and the initial values were taken from the innermost plateau observed in Grt II of C05. Given these initial conditions and implying a parabolic $\mathrm{T}-\mathrm{t}$ trajectory in the temperature interval of 570 to $600^{\circ} \mathrm{C}$ we obtain a duration on the order of $0.2 \mathrm{Ma}$ for the high-temperature stage of Eo-Alpine metamorphism. This indicates that Eo-Alpine metamorphism was a rather short-lived event. This finding is compatible with what is known from geochronology about the timing of the EoAlpine event. A compilation of geochronological data from the Eastern Alps (Thöni 2006) clearly shows that Eo-Alpine metamorphism culminated with eclogite facies conditions in the Kor- and Saualpe regions and with amphibolite facies conditions in the Wölz and Rappold Complexes at about $92 \mathrm{Ma}$ and that all Austroalpine units were cooled to temperatures below about $300^{\circ} \mathrm{C}$ at $80 \mathrm{Ma}$. A short duration of the Eo-Alpine event was also inferred from the diffusion profiles at Grt I/Grt II interfaces form Faryad and Chakraborty (2005). In addition, a relatively long duration of the Permian event and a comparatively short duration of the Eo-Alpine event was also inferred by Gaidies et al. (2008b) from the modification of the garnet growth zoning by intracrystalline diffusion during growth and subsequent high-temperature annealing which is only discernible in the Permian Grt I cores and almost entirely absent in the Grt II rims of garnets from the Wölz Complex.

Based on the assumption that the concentrations at the crack surface were constant during diffusion and similar to the present day compositions, our calculations point to crack formation during cooling below about $450^{\circ} \mathrm{C}$ with a considered cooling rate of $30^{\circ} \mathrm{C} / \mathrm{Ma}$ (Fig. 10).

It must be noted that the timescales inferred from diffusion modelling are strongly dependent on the choice of tracer diffusion coefficients. We used the diffusion coefficients of Chakraborty and Ganguly (1992) because they are the only ones that reproduce the observed complex zoning patterns correctly in a qualitative sense, i.e. the relative diffusivities correspond well to the diffusion profiles observed for the different cations. This is why we believe that the set of tracer diffusion coefficients given by these latter authors for $\mathrm{Fe}^{2+}, \mathrm{Ca}^{2+}, \mathrm{Mg}^{2+}$ and $\mathrm{Mn}^{2+}$ best reflects cation diffusion in the garnet lattice. Substantially shorter time scales would be obtained if the tracer-diffusion coefficients were taken from Ganguly et al. (1998) or from Carlson (2002). We do not refer to these self-diffusion coefficients because they do not reproduce the observed complex zoning, i.e. the relative diffusivities do not correspond well with the observed concentration profiles.

\section{Conclusions}

In polymetamorphic rocks the parageneses that were generated during an early stage of the metamorphic evolution may be largely obliterated in the course of repeated metamorphic overprints. Due to its refractory nature garnet may be the only source of information for the reconstruction of possible metamorphic conditions during early stages of the metamorphic history motivating the application of garnet isopleth thermobarometry. In this study, garnet isopleth thermobarometry was applied to two growth zones of garnet from the Wölz Complex. For this purpose garnet grains were selected that are devoid of latestage re-equilibration phenomena and show concentric chemical zoning delineating their idiomorphic crystal shapes. As a result it was found that the first growth zone formed at pressures of 400 to $500 \mathrm{MPa}$ and temperatures of 540 to $560^{\circ} \mathrm{C}$. This growth zone was dated at $269 \pm 4 \mathrm{Ma}$ by Schuster and Thöni (1996) and reflects a low-pressure thermal overprint during the Permian. Permian metamorphism is probably due to elevated heat flow during incipient rifting and crustal thinning of the continental crust, which later becomes the Austroalpine units during the Permian and lower Triassic. For the second growth zone we infer pressures in the range of 700 to $800 \mathrm{MPa}$ at temperatures of 550 to $570^{\circ} \mathrm{C}$. This growth zone is ascribed to the Eo-Alpine overprint at $\sim 90 \mathrm{Ma}$. It reflects the Barrovian-type metamorphism that was associated with continent-continent collision during the Cretaceous.

Garnet I from the Wölz and Rappold Complexes may show compositional zoning, which deviates from the supposed original growth zoning. Such phenomena are considered a secondary modification of the original growth zoning by diffusion-controlled exchange with the rock matrix or by diffusion-controlled exchange with garnet rims. Two generations of alteration phenomena may be discerned. A first generation of alteration phenomena extends over several $100 \mu \mathrm{m}$ into the pre-existing Grt I 
and is ascribed to exchange of Grt I with the rock matrix during a long-lasting high-temperature anneal associated with Permian metamorphism. A second generation of alteration phenomena is restricted to an about $50 \mu \mathrm{m}$ wide zone within Grt I towards its interface to Grt II. These alteration phenomena are ascribed to diffusion-controlled exchange between Grt I and Grt II during Eo-Alpine metamorphism. Whereas the time scales obtained for the high-temperature stage of the Permian event are on the order of $10 \mathrm{Ma}$, the time scale obtained for the Eo-Alpine event is only on the order of $0.2 \mathrm{Ma}$. This reflects the longlived nature of a stage of elevated heat flux and a high geothermal gradient associated with an extensional regime in the Austroalpine realm during the Permian and the lower Triassic. The comparatively short duration of the Eo-Alpine event reflects rapid exhumation of the Austroalpine lower plate subsequent to subduction associated with continentcontinent collision during the Cretaceous.

Acknowledgements This work was funded by DFG research grant AB 314/2-1 in the framework of the FOR 741 research group. We thank Ralf Milke for his help on the electron microprobe, Ralf Schuster for his lead in the field and Georg Hoinkes, Lukas Keller, and Sha-Wali Faryad for stimulating discussion.

\section{References}

Abart R, Martinelli W (1989) Alpidische und variszische Entwicklungsgeschichte des Wölzer Kristallins. Mitt Ges Geol Bergbaustud Österr 37:1-14

Carlson WD (1991) Competitive diffusion-controlled growth of porphyroblasts. Mineral Mag 55:317-330

Carlson WD (2002) Scales of disequilibrium and rates of equilibration during metamorphism. Am Mineral 87:185-204

Chakraborty S, Ganguly J (1992) Cation diffusion in aluminosilicate garnets: experimental determination in spessartine-almandine diffusion couples, evaluation of effective binary, diffusion coefficients, and applications. Contrib Mineral Petrol 111:74-78

Connolly JAD (1990) Multivariable phase diagrams: an algorithm based on generalized thermodynamics. Am J Sci 290:666-718

Connolly JAD, Petrini K (2002) An automated strategy for calculation of phase diagram sections and retrieval of rock properties as a function of physical conditions. J Metamorph Geol 20:697-708

Faryad SW, Chakraborty S (2005) Duration of Eo-Alpine metamorphic events obtained from multicomponent diffusion modeling of garnet: a case study from the Eastern Alps. Contrib Mineral Petrol 150:306-318

Faryad SW, Hoinkes G (2003) P-T gradient of Eo-Alpine metamorphism within the Austroalpine basement units east of the Tauern Window (Austria). Mineral Petrol 77:129-159

Gaidies F, Abart R, de Capitani C, Schuster R, Connolly JAD, Reusser E (2006) Characterisation of polymetamorphism in the Austroalpine basement east of the Tauern Window using garnet isopleth thermobarometry. J Metamorph Geol 24:451-475

Gaidies F, de Capitani C, Abart R (2008a) THERIA_G: a software program to numerically model prograde garnet growth. Contrib Mineral Petrol 155:657-671
Gaidies F, de Capitani C, Abart R, Schuster R (2008b) Prograde garnet growth along complex $\mathrm{P}-\mathrm{T}-\mathrm{t}$ paths: results from numerical experiments on polyphase garnet from the Wölz Complex (Austroalpine basement). Contrib Mineral Petrol 155:673-688

Gaidies F, Krenn E, de Capitani C, Abart R (2008c) Coupling forward modelling of garnet growth with monazite geochronology: an application to the Rappold Complex (Austroalpine crystalline basement). J Metamorph Geol 26:775-793

Ganguly J, Cheng WJ, Chakraborty S (1998) Cation diffusion in aluminosilicate garnets: experimental determination in pyropealmandine diffusion couples. Contrib Mineral Petrol 131:171180

Hoinkes G, Koller F, Rantisch G et al (1999) Alpine metamorphism of the Eastern Alps. Schweiz Mineral Petrogr Mitt 79:155-181

Holland TJB, Powell R (1998) An internally consistent thermodynamic data set for phases of petrological interest. J Metamorph Geol 16:309-343

Keller L, Abart R, Wirth R, Schmid D, Kunze K (2006) Enhanced mass transfer through short circuit diffusion: growth of garnet reaction rims at eclogite facies conditions. Am Mineral 91:1024-1038

Keller L, Hauzenberger CA, Abart R (2007) Diffusion along interphase boundaries and its effect on retrograde zoning patterns of metamorphic minerals. Contrib Mineral Petrol 154:205-216

Lasaga AC (1979) Multicomponent exchange and diffusion in 861 silicates. Geochim Cosmochim Acta 43:455-469

Prenzel J, Abart R (2009) Prograde breakdown of staurolite in polymetamorphic micaschists from the Rappold complex, Austroalpine basement, Eastern Alps. Mineral Petrol (this volume)

Prenzel J, Abart R, Keller L (2009) Complex chemical zoning in eclogite facies garnet reaction rims: the role of grain boundary diffusion. Mineral Petrol 95:303-313

Schmid SM, Fügenschuh B, Kissling E, Schuster R (2004) Tectonic map and overall architecture of the Alpine orogen. Eclogae Geol Helv 97:61-77

Schuster R, Frank W (1999) Metamorphic evolution of the Austroalpine units east of the Tauern Window: indications for Jurassic strike slip tectonics. Mitt Ges Geol Bergbaustud Österr 42:37-58

Schuster R, Thöni M (1996) Permian garnets: indication for a regional Permian metamorphism in the southern part of the Austroalpine basement units. Mitt Ges Geol Bergbaustud Österr 141:219-221

Schuster R, Schabert S, Abart R, Frank W (2001) Permo-Triassic extension and related HT/LP metamorphism in the AustroalpineSouthalpine realm. Mitt Ges Geol Bergbaustud Österr 45:111141

Schuster R, Koller F, Hoeck V, Hoinkes G, Bousquet R (2004) Explanatory notes to the map: metamorphic structure of the AlpsMetamorphic evolution of the Eastern Alps. Mitt Österr Mineral Ges 149:179-199

Spear FS, Selverstone J (1983) Quantitative P-T paths from zoned minerals: theory and tectonic applications. Contrib Mineral Petrol 83:348-357

Symmes GH, Ferry JM (1991) Evidence from mineral assemblages for infiltration of pelitic schists by aqueous fluids durino metamorphism. Contrib Mineral Petrol 108:419-438

Thöni M (2002) Sm-Nd isotope systematics in garnet from different lithologies (Eastern Alps): age results, and an evaluation of potential problems for garnet Sm-Nd chronometry. Chem Geol 185:255-281

Thöni M (2006) Dating eclogite-facies metamorphism in the Eastern Alps approaches, results, interpretations: a review. Mineral Petrol 88:123-148

Vance D, Holland TJB (1993) A detailed isotopic and petrological study of a single garnet from the Gassetts Schist, Vermont. Contrib Mineral Petrol 114:101-118 